\title{
Organic Records of Early Life on Mars: The Role of Iron, Burial, and Kinetics on Preservation
}

Jonathan Tan and Mark A. Sephton

\begin{abstract}
Samples that are likely to contain evidence of past life on Mars must have been deposited when and where environments exhibited habitable conditions. Mars analog sites provide the opportunity to study how life could have exploited such habitable conditions. Acidic iron- and sulfur-rich streams are good geochemical analogues for the late Noachian and early Hesperian, periods of martian history where habitable conditions were widespread. Past life on Mars would have left behind fossilized microbial organic remains. These are often-sought diagnostic evidence, but they must be shielded from the harsh radiation flux at the martian surface and its deleterious effect on organic matter. One mechanism that promotes such preservation is burial, which raises questions about how organic biomarkers are influenced by the postburial effects of diagenesis. We investigated the kinetics of organic degradation in the subsurface of Mars. Natural mixtures of acidic iron- and sulfur-rich stream sediments and their associated microbial populations and remains were subjected to hydrous pyrolysis, which simulated the increased temperatures and pressures of burial alongside any promoted organic/mineral interactions. Calculations were made to extrapolate the observed changes over martian history. Our experiments indicate that low carbon contents, high water-to-rock ratios, and the presence of iron-rich minerals combine to provide unfavorable conditions for the preservation of soluble organic matter over the billions of years necessary to produce present-day organic records of late Noachian and early Hesperian life on Mars. Successful sample selection strategies must therefore consider the pre-, syn-, and postburial histories of sedimentary records on Mars and the balance between the production of biomass and the long-term preservation of organic biomarkers over geological time. Key Words: MarsBiosignature-Hydrous pyrolysis-Kinetic parameters-Lipids-Artificial maturation. Astrobiology 20, 53-72.
\end{abstract}

\section{Introduction}

$S$ UCCESS IN THE SEARCH for evidence of life on Mars depends on selecting the appropriate samples for investigation. The late Noachian and early Hesperian period of martian history provide samples of a time when conditions were habitable and when any martian life would have had a relatively lengthy opportunity to originate and proliferate (Cockell, 2014; Westall et al., 2015). During the Hesperian period of Mars' history, acidic, sulfur-rich conditions led to the regional deposition of abundant sulfate minerals, such as gypsum $\left(\mathrm{CaSO}_{4} \cdot 2 \mathrm{H}_{2} \mathrm{O}\right)$ and jarosite $\left(\mathrm{KFe}_{3}^{3+}(\mathrm{OH})_{6}\left(\mathrm{SO}_{4}\right)_{2}\right)$, in aqueous conditions (Klingelhöfer et al., 2004; Squyres et al., 2004; Gendrin et al., 2005). Although the longevity of these environments is uncertain, they may have been capable of supporting extremophilic organisms that produced organic remains that, when entombed in a mineral matrix, could represent fossil organic biomarkers in the martian rock record. For this reason, there has been significant interest in the ability of jarosite, or minerals associated with jarosite, to preserve organic matter (Aubrey et al., 2006; Kotler et al., 2008; Lewis et al., 2015).

Recent work has shown that lipids are concentrated in iron oxyhydroxides (such as goethite) associated with acid sulfate environments and can preserve fatty acid profiles beyond the initial stages of diagenesis (Tan et al., 2018). The iron oxides and oxyhydroxides present in these environments have also been found to be significantly more amenable to thermal extraction techniques (e.g., pyrolysis) used to search for organic matter when compared with minerals that release oxygen upon heating, such as sulfates (such as jarosite) and perchlorates (Lewis et al., 2018). Consequently, iron oxides and oxyhydroxides associated with sulfur stream environments should be considered targets of astrobiological interest.

Department of Earth Science and Engineering, Impacts and Astromaterials Research Centre, Imperial College London, London, United Kingdom.

(C) Jonathan Tan and Mark A. Sephton, 2019; Published by Mary Ann Liebert, Inc. This Open Access article is distributed under the terms of the Creative Commons Attribution Noncommercial License (http://creativecommons.org/licenses/by-nc/4.0/) which permits any noncommercial use, distribution, and reproduction in any medium, provided the original author(s) and the source are credited. 
Little is known, however, about how organic biomarkers may be degraded by reactions involving both the organic and inorganic constituents of these acidic iron- and sulfur-rich stream samples, especially following burial where temperature and pressure are elevated for extended periods of time.

If life arose on Mars at the same time as Earth, when conditions on both planets were relatively similar, its remains would need to survive billions of years to be detectable in the present day. Although the martian ultraviolet (UV) flux may have been comparable with early Earth and hence not an inhibitor of the evolution of early life (Cockell, 2000), the cumulative effects of UV radiation over martian history would likely have destroyed all traces of surface organic matter, or at the very least have rendered organic biomarkers indistinguishable from abiotic carbon sources (Dartnell, 2011; Hassler et al., 2014). Radiation raises some concerns for iron-rich environments, as iron may promote the destruction of organic matter in Mars' present-day radiation environment (Hassler et al., 2014). Thus, to avoid the deleterious effects of UV radiation, rocks containing organic biomarkers would need to have been rapidly transported to the subsurface where further exposure to the effects of UV would be avoided (Cockell, 2014; Hassler et al., 2014). Buried surfaces can be accessed in the present day by using a drill as planned in the forthcoming ExoMars (2020) mission (Vago et al., 2016), or by searching for surfaces that have only relatively recently been exhumed such as near escarpments (Farley et al., 2014) or sites of impact ejection (Montgomery et al., 2016).

Burial on Mars is relatively rare owing to a lack of plate tectonics, but does occur mostly following continuous sedimentation and subsequent compaction, as observed in Gale Crater (Edgett et al., 2016; Caswell and Milliken, 2017). The sediments observed at Yellowknife Bay, for example, were deeply buried and exhumed before 3.3 to $3.2 \mathrm{Ga}$, and analysis of the hydraulic fracturing within the mudstones of this unit shows a minimum burial depth of $1.2 \mathrm{~km}$ (Caswell and Milliken, 2017). Peak burial temperatures at such depths would depend on the geothermal gradient, which has changed throughout Mars' geological history. Present-day estimates range from 6.4 to $10.6 \mathrm{~K} / \mathrm{km}$ (Hoffman, 2001), while modeling of the diagenetic history of Gale Crater suggests a timedependent variable geothermal gradient, with peak paleotemperatures for sedimentary rocks at Gale Crater ranging from $80^{\circ} \mathrm{C}$ to $225^{\circ} \mathrm{C}$, depending on factors such as surface temperature, overburden thickness, thermal conductivity, and heat flow (Borlina et al., 2015). Consequently, organic biomarkers that have been buried will have been subjected to other potentially degrading mechanisms, and must have been able to survive elevated temperatures, pressures, and degradative reactions involving the interaction of minerals with organic matter.

To achieve a full appreciation of how organic biomarkers could be preserved on Mars, it is important to understand how these materials are influenced by the postburial effects of diagenesis, especially with regard to the interactions between organic matter and the mineral matrices present in these distinct martian geochemical environments. Previous studies of Mars-relevant sulfur-rich analogues examined surface conditions where extant biomass was still present. The ability of organic matter hosted in Mars analog settings to survive the initial stages of diagenesis and subsequent burial and thermal maturation has not been previously addressed (e.g.,
Fernández-Remolar, 2003; Benison and Bowen, 2006; Parenteau et al., 2014; Williams et al., 2015; Tan et al., 2018).

Hydrous pyrolysis is a well-known technique used to artificially mature organic matter-rich samples in the laboratory (e.g., Lewan, 1985), but has also been used to simulate the effects of diagenesis on certain biomarkers (e.g., Lewan et al., 1986; Eglinton and Douglas, 1988; Peters et al., 1990; Koopmans et al., 1996; Jaeschke et al., 2008). Hydrous pyrolysis involves heating a sample containing both sediment and organic matter in a closed system in the presence of an inert atmosphere and deoxygenated water at subcritical temperatures for $72 \mathrm{~h}$ (Lewan et al., 1979; Lewan, 1983). Historically, hydrous pyrolysis has been used to study rocks with a high total organic carbon (TOC) content, with diagenesis being studied at temperatures between $160^{\circ} \mathrm{C}$ and $280^{\circ} \mathrm{C}$ (Eglinton and Douglas, 1988; Peters et al., 1990; Koopmans et al., 1995) and catagenesis being investigated between $300^{\circ} \mathrm{C}$ and $365^{\circ} \mathrm{C}$ (Lewan et al., 1979). Iron-rich rocks with low TOC, such as those found in Mars analog environments, have thus not been widely investigated by using this method. In this study, microbial mat materials hosted in two mineralogically distinct Mars-relevant acidic iron- and sulfur-rich stream environments were artificially matured with hydrous pyrolysis to investigate the effects of thermal diagenesis and associated mineral matrix-assisted reactions on the preservation of organic matter within these samples.

\section{Materials and Methods}

\subsection{Sample description}

The samples used in this study were collected from two acidic iron- and sulfur-rich streams in Dorset, United Kingdom. The first acid stream was located in St. Oswald's Bay (Fig. 1a) and actively flows from slumped Wealden Beds rich in pyrite (Kemp et al., 2012), resulting in the deposition of iron sulfates and oxyhydroxides in an acidic environment with waters of $\mathrm{pH}$ 3.5. Jarosite deposition was observed in areas with low water-to-rock ratios, while goethite was found capping jarosite layers where the soils were waterlogged. The stream was observed to host a distinct sulfur-based microbial ecosystem that comprised acidophilic algae, microbial mats of phototrophic purple sulfur bacteria, and charcoal wood fragments from the surrounding bankside. A more detailed description of the geology of the study area and the samples collected can be found in the literature (Tan et al., 2018).

The second acid stream was present at Stair Hole (Fig. 1b). This was a smaller stream that possessed a weaker flow and a higher $\mathrm{pH}$ (5) than observed in St. Oswald's Bay. At Stair Hole, no green biological matter was observed on first inspection, although a thin microbial mat separated itself from the top of the core after it was freeze-dried. Extracted cores (Fig. 1c, d) were packaged in aluminum foil and returned to the laboratory where they were immediately freeze-dried. Individual organic matter and mineral layers within each core were separated using a solvent-cleaned saw washed with methanol and dichloromethane (DCM) to preclude contributions from contamination. The samples were subsequently ground and homogenized with a ceramic pestle and mortar to allow for X-ray diffraction (XRD) analysis and lipid extraction. Sample mineralogy was previously assessed by XRD and quantified using Rietveld refinement (Table 1) (Lewis et al., 2018). 

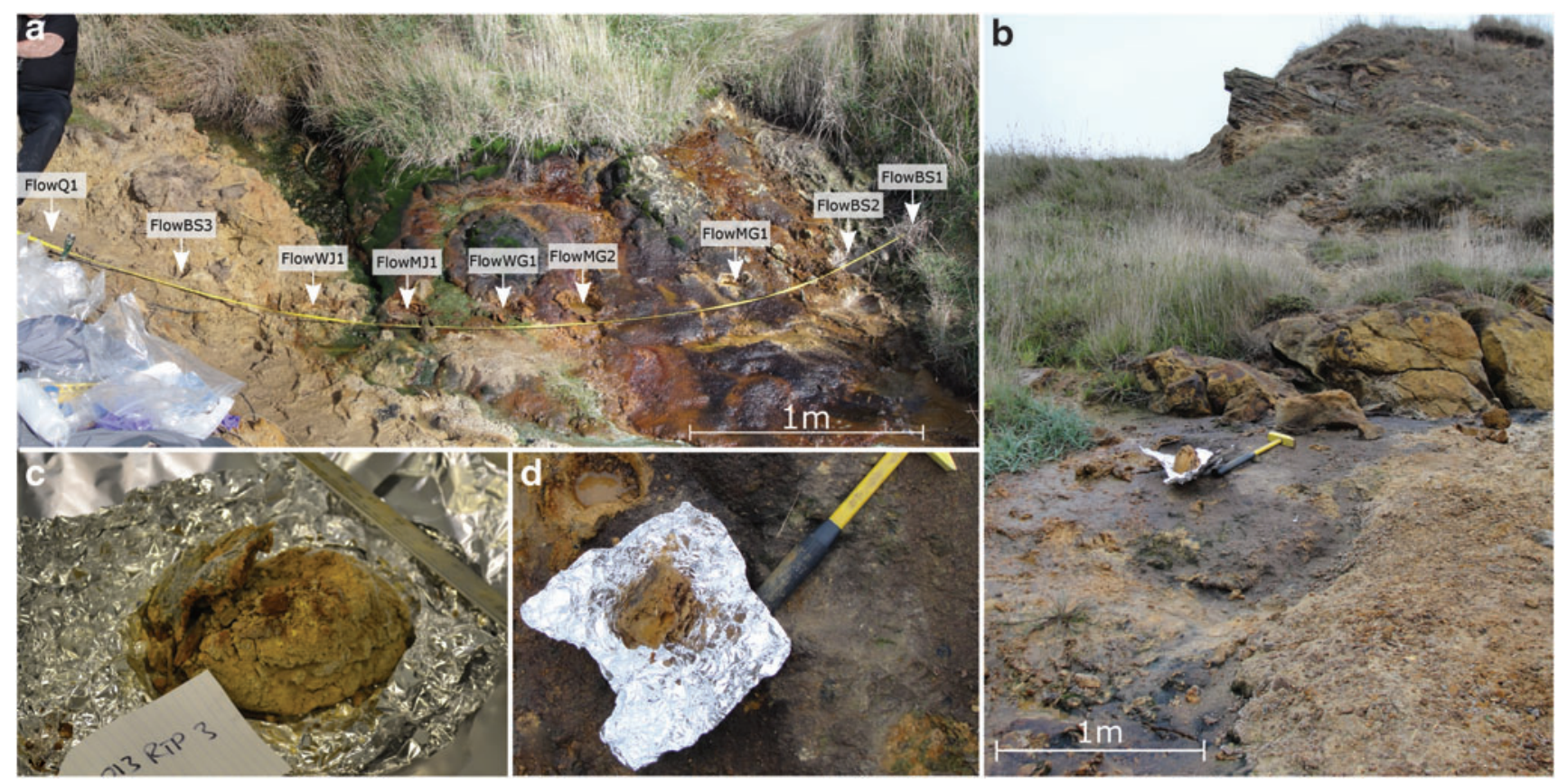

FIG. 1. Field and laboratory photographs of the acid streams and samples taken from Dorset, United Kingdom. (a) Ironrich sulfur stream found at St. Oswald's Bay. Each arrow represents a core sampled from this location. (b) Overview of the acid stream at Stair Hole. (c) Laboratory photograph of a core taken from the center of the acid stream from (a). (d) Field photograph of a core extracted from the acid stream in (b). Photographs courtesy of James Lewis (2018). Color images are available online.

Two samples, FlowMG1a (taken from St. Oswald's Bay and hereafter referred to as the clay-poor stream sample) and DryMJ1a (taken from Stair Hole and hereafter referred to as the clay-rich stream sample), were chosen for artificial maturation by hydrous pyrolysis. The two samples represented examples of soils with high goethite and minor jarosite content, with the clay-rich stream sample also containing a significant proportion of illite and kaolinite. Microbial mat material was also observed in both samples.

\subsection{Artificial maturation by hydrous pyrolysis}

A typical setup for a hydrous pyrolysis experiment has been described previously (Sephton et al., 1999). A hightemperature and high-pressure stainless steel reactor $(70 \mathrm{~mL}$ Model 4740, Parr Instruments) was used for our experiments. Owing to the small size of the stream samples, as well as concerns about the acidity of the components, small stainless steel "bomblets" were constructed. These inserts

Table 1. Samples, Sample Codes, and Conditions Chosen for Hydrous Pyrolysis Experiments

\begin{tabular}{|c|c|c|c|c|}
\hline Sample code & Locality & $W: R$ ratio & Pyrolysis temp. $\left({ }^{\circ} \mathrm{C}\right)$ & $X R D$ data \\
\hline \multicolumn{5}{|l|}{ Clay-poor stream } \\
\hline FlowMG1a-Unheated & St. Oswald's Bay & N/A & N/A & Q: $64, \mathrm{G}: 26, \mathrm{~J}: 10, \mathrm{I}: 0, \mathrm{~K}: 0, \mathrm{M}: 0$ \\
\hline FlowMG1aL-200 $\mathrm{C}$ & St. Oswald's Bay & $5: 1$ & 200 & Same as FlowMG1a-Unheated \\
\hline FlowMG1aL-240 ${ }^{\circ} \mathrm{C}$ & St. Oswald's Bay & $5: 1$ & 240 & Same as FlowMG1a-Unheated \\
\hline FlowMG1aL-280 $20^{\circ} \mathrm{C}$ & St. Oswald's Bay & $5: 1$ & 280 & Same as FlowMG1a-Unheated \\
\hline FlowMG1aH$-200^{\circ} \mathrm{C}$ & St. Oswald's Bay & $1: 1$ & 200 & Same as FlowMG1a-Unheated \\
\hline FlowMG1aH$-240^{\circ} \mathrm{C}$ & St. Oswald's Bay & $1: 1$ & 240 & Same as FlowMGla-Unheated \\
\hline FlowMG1aH-280 ${ }^{\circ} \mathrm{C}$ & St. Oswald's Bay & $1: 1$ & 280 & Same as FlowMG1a-Unheated \\
\hline \multicolumn{5}{|l|}{ Clay-rich stream } \\
\hline DryMJ1a-Unheated & Stair Hole & N/A & N/A & Q: 40, G: 18, J: 6 , I: $25, \mathrm{~K}: 11, \mathrm{M}:$ \\
\hline DryMJ $1 \mathrm{aL}-200^{\circ} \mathrm{C}$ & Stair Hole & $5: 1$ & 200 & Same as DryMJ1a-Unheated \\
\hline DryMJ1aL-2 $240^{\circ} \mathrm{C}$ & Stair Hole & $5: 1$ & 240 & Same as DryMJ1a-Unheated \\
\hline DryMJ1aL- $280^{\circ} \mathrm{C}$ & Stair Hole & $5: 1$ & 280 & Same as DryMJ1a-Unheated \\
\hline DryMJ $1 \mathrm{aH}-200^{\circ} \mathrm{C}$ & Stair Hole & $1: 1$ & 200 & Same as DryMJ1a-Unheated \\
\hline DryMJ $1 \mathrm{aH}-240^{\circ} \mathrm{C}$ & Stair Hole & $1: 1$ & 240 & Same as DryMJ1a-Unheated \\
\hline DryMJ1aH-280 ${ }^{\circ} \mathrm{C}$ & Stair Hole & $1: 1$ & 280 & Same as DryMJ1a-Unheated \\
\hline
\end{tabular}

All samples were pyrolyzed for $72 \mathrm{~h}$.

$\mathrm{G}=$ goethite; $\mathrm{I}=$ illite; $\mathrm{J}=$ jarosite; $\mathrm{K}=$ kaolinite; $\mathrm{M}=$ montmorillonite; $\mathrm{Q}=$ quartz; $\mathrm{W}: \mathrm{R}=$ water-to-rock ratio; $\mathrm{XRD}=\mathrm{X}$-ray diffraction. 
were built using $4 \mathrm{~cm}$ of T316 stainless steel tube $(35 \times 9 \mathrm{~mm}$ o.d. $\times 6 \mathrm{~mm}$ i.d.) and sealed with Swagelok end caps (SS600-C) following deburring. The bomblets reduced the effective internal volume of the reactor from $\sim 70$ to $1.5 \mathrm{~mL}$. The bomblets were ultrasonically washed in water, methanol, and DCM, and then dried at $110^{\circ} \mathrm{C}$ before analysis.

Approximately $200 \mathrm{mg}$ of sample was added to each bomblet, and 0.1 to $0.5 \mathrm{~mL}$ of degassed deionized (DI) water was also added depending on the water-to-rock ratios that were to be tested. The bomblets were then sealed in a nitrogen atmosphere to avoid sample oxidation and shaken to ensure homogenization. Up to two bomblets were then inserted into the $70 \mathrm{~mL}$ Parr reaction vessel. Twenty milliliters of degassed DI water was added to the reaction vessel to maintain the correct pressure, as well as to ensure a reduced pressure differential across the bomblet walls. The reactor was then sealed and placed into an oven, with the temperature and pressure of the vessel measured with a thermocouple and pressure gauge, respectively. Hydrous pyrolysis was performed on samples at $200^{\circ} \mathrm{C}, 240^{\circ} \mathrm{C}$, and $280^{\circ} \mathrm{C}$ for $72 \mathrm{~h}$ (Table 1). The reactor was then removed and allowed to cool before removing the inserts for extraction.

\subsection{Pyrolysate extraction}

Once the heating procedure was complete and an insert was unsealed, the water contained within the bomblet was transferred to a separating funnel. The solid residue was then ultrasonically extracted by methanol $(3 \times)$, DCM:methanol $(1 / 1, v / v)(3 \times)$, and DCM $(3 \times)$, with the supernatants transferred to the same separating funnel as the water from the insert, and a liquid/liquid extraction performed with excess DI water. The solvents were concentrated using a rotary evaporator and dried with anhydrous sodium sulfate.

The pyrolysates were then treated with boron trifluoride in methanol ( $\mathrm{BF}_{3}$-methanol) (Tan et al., 2018) to break any ester bonds present. This transesterification treatment liberated fatty acids and converted them to fatty acid methyl esters that were more amenable to gas chromatography/mass spectrometry (GC-MS) analysis. The pyrolysates were then further derivatized with 99-1 N,O-bis(trimethylsilyl) trifluoroacetamide (BSTFA)-trimethylchlorosilane (TMCS).

\subsection{Gas chromatography/mass spectrometry}

The pyrolysates were analyzed by GC-MS using an Agilent Technologies $7890 \mathrm{~N}$ gas chromatography (GC) coupled to an Agilent Technologies 5975C mass selective detector. One microliter of sample was injected at a 10:1 split ratio at $270^{\circ} \mathrm{C}$ and separation was performed by a DB-5MSUI column $(30 \mathrm{~m} \times 0.25 \mathrm{~mm} \times 0.25 \mu \mathrm{m} ; \mathrm{J} \& \mathrm{~W})$, with helium as a carrier gas at a constant column flow of $11 \mathrm{~mL} \mathrm{~min}{ }^{-1}$. The GC oven temperature was initially held at $80^{\circ} \mathrm{C}$ for $2 \mathrm{~min}$ and then ramped at $5^{\circ} \mathrm{C} \min ^{-1}$ to $310^{\circ} \mathrm{C}$ where it was held for $14 \mathrm{~min}$. Mass spectra were acquired in the scan range (45$550 \mathrm{amu}$ ). Peak identification was based on retention time and mass spectra comparisons with authenticated standards and by reference to the NIST-08 mass spectral database.

\subsection{Kinetic parameter modeling}

Hydrous pyrolysis is used to study the diagenesis and maturation of organic compounds as it replicates the organic geochemical reactions that occur over geological timescales by simulating them with short-term, high-temperature, and high-pressure laboratory conditions; this technique has been utilized by several authors to study the effects of thermal maturity on specific biomarker compounds (e.g., Eglinton et al., 1986; Peters et al., 1990; Koopmans et al., 1995; Jaeschke et al., 2008; Rush et al., 2014; Royle et al., 2018). It is thus possible to derive the kinetic parameters of these organic degradation reactions, including any additional effects promoted by the interactions between the organic matter and the mineral matrix, from the results of hydrous pyrolysis, allowing modeling of the preservation of a group of organic compounds over martian geological time (Lewan, 1985; Hunt et al., 1991; Royle et al., 2018). Previous work has shown that natural organic maturation can be approximated by pseudo-first-order reaction kinetics (Lewan, 1985; Lewan et al., 1986). The Arrhenius equation (Eq. 1) relates the reaction rate constant, $k\left(\mathrm{~s}^{-1}\right)$, the absolute temperature $T$ (in $\mathrm{K}$ ), the gas constant $R\left(\mathrm{~J} \cdot \mathrm{mol}^{-1} \cdot \mathrm{K}^{-1}\right)$, the activation energy $E\left(\mathrm{~J} \cdot \mathrm{mol}^{-1}\right)$, and the Arrhenius constant $A\left(\mathrm{~s}^{-1}\right)$. From this relationship, it is possible to determine the change in concentration of the reactants (the organic compounds of interest) over time at any constant temperature.

$$
\kappa=A e^{-\frac{E}{R T}}
$$

Using these kinetic relationships, we approximated the rate of lipid degradation over geological time under Mars analog conditions, and thus predicted the fate of lipids in similar environments on Mars.

\section{Results}

The hydrous pyrolysates of the clay-poor stream sample and the clay-rich stream sample after treatment at $200^{\circ} \mathrm{C}$, $240^{\circ} \mathrm{C}$, and $280^{\circ} \mathrm{C}$ contained similar groups of lipids, including saturated, unsaturated, and branched (both terminal and midchain) fatty acids. $\omega$-Hydroxy fatty acids and polycyclic terpene phytosteroids were also observed, both of which are products derived from higher plants. A more indepth analysis, comparison, and discussion of the deposition environments, lipid diversity, and key biomarkers present in each of the two sampling areas are reported in the work of Tan et al. (2018).

Briefly, the overall lipid profiles of both core samples were found to be similar (Fig. 2); this, when taken into consideration with the similar depositional environments and key biomarkers, implied the presence of similar microbial communities in the two sampling locations. The primary difference between the samples was the paucity of $\omega$-hydroxy fatty acids in the clay-rich stream sample, which was likely due to less plant material found near that core. Another difference was the higher relative abundance of the 10Me-16:0 biomarker that is characteristic of sulfurreducing bacteria (SRB) in the clay-poor stream sample (Vestal and White, 1989; Zhang et al., 2002), suggesting that there was a larger SRB population hosted at St. Oswald's Bay compared with that at Stair Hole.

Given the observations of similar depositional environments and comparable microbial communities, the key difference between the hydrous pyrolysis products of both samples in the following experiments must have been a 


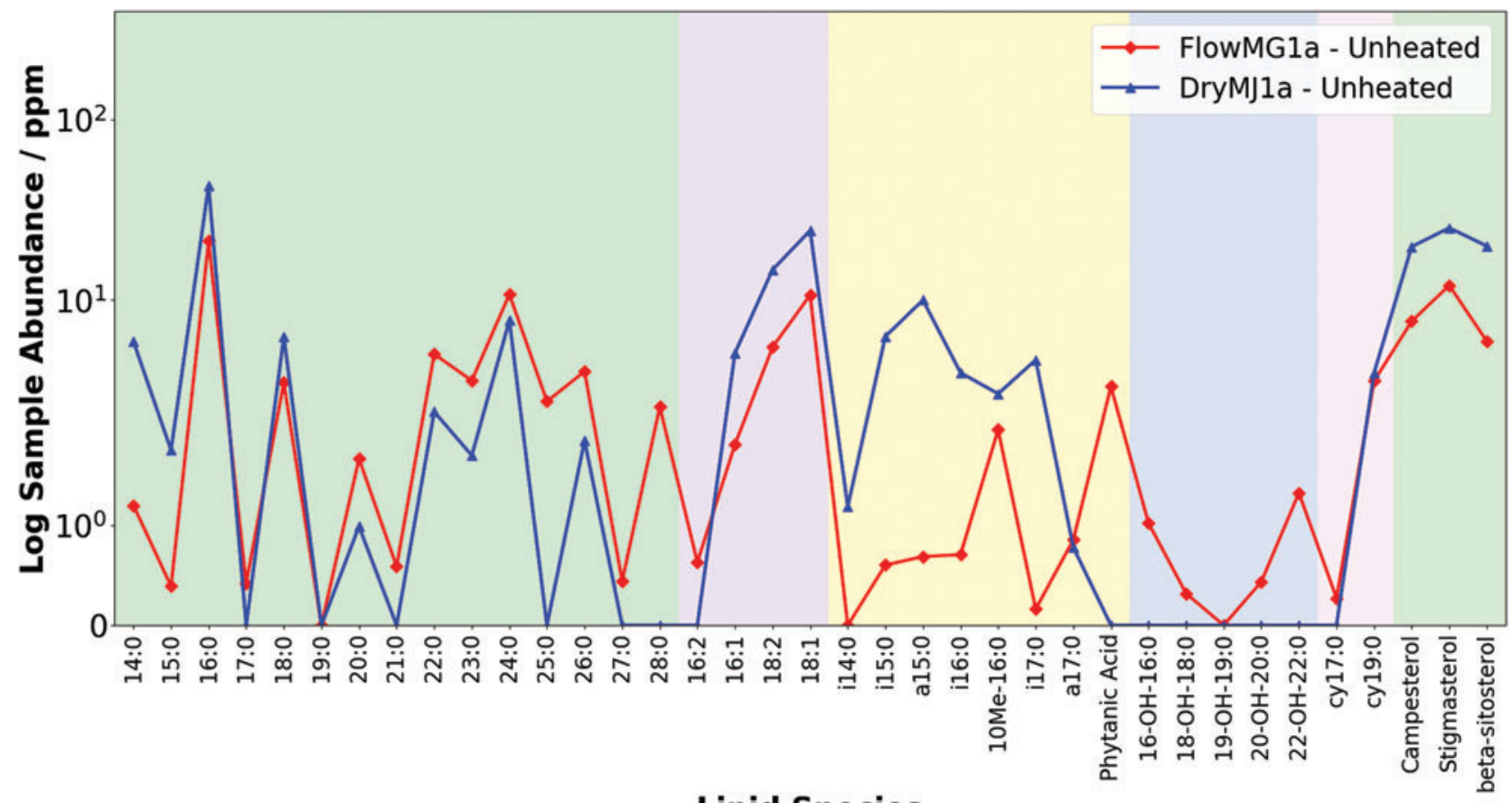

Lipid Species

FIG. 2. Lipid abundances from the raw (unpyrolyzed) samples of the stream. Lipid classes are indicated by the different colored backgrounds: green, saturated fatty acids; purple, unsaturated fatty acids; yellow, branched fatty acids; blue, hydroxy-fatty acids; pink, cyclopropyl fatty acids; lime green, phytosterols. This color scheme is used for all graphs. Color images are available online.

result of their differing mineralogy, as well as the variations in water-to-rock conditions under which they were artificially matured.

\subsection{Clay-poor stream sample}

The clay-poor stream sample (FlowMG1a) comprised a microbial mat over goethite minerals. The sample was made up of $64 \%$ quartz, $26 \%$ goethite, and $10 \%$ jarosite and contained a proportion of microbial mat material previously examined in the work of Tan et al. (2018). The provenance of goethite and jarosite in this sample was described previously (Lewis et al., 2015; Tan et al., 2018).

The abundance of each species of lipid decreased with increasing simulated maturation level, likely resulting from either the defunctionalization of labile fatty acids with increasing pressure and temperature, or via the oxidation of organic matter by interacting with iron oxyhydroxides present within the sample (Fig. 3a, b). Oxidation by iron minerals is the more likely mechanism for fatty acid destruction, as the defunctionalization of fatty acids should result in the production of alkanes, which were absent in all samples analyzed.

The degree of lipid degradation varied with species (Fig. 3c, d): the saturated fatty acid fraction exhibited a minimal decrease, with a loss of $27.7 \%$ and $9.2 \%$ saturates between $200^{\circ} \mathrm{C}$ to $240^{\circ} \mathrm{C}$ and $240^{\circ} \mathrm{C}$ to $280^{\circ} \mathrm{C}$, respectively. These data can be compared with an average of $81.4 \%$ and $33.7 \%$ loss of organic matter per stepwise increase in temperature for the unsaturated and branched fatty acids, respectively, particularly the complete loss of the 18:2 species at $280^{\circ} \mathrm{C}$, and the loss of all branched fatty acids under high water-to-rock ratios. More structurally complex lipids suffered the most degradation, with cyclopropyl fatty acids and sterols being destroyed at $240^{\circ} \mathrm{C}$ and $280^{\circ} \mathrm{C}$, respectively. Despite the loss in abundance of individual lipids, the overall pattern of the lipid profile was preserved relatively well despite the increasing simulated maturation level, particularly the retention of the even-over-odd predominance (EOP) in the carbon-chain length of the saturated fatty acids, a biogenic signature that is useful for distinguishing biomarkers from abiotic organic carbon.

There was a clear difference in the ability of these environments to preserve organic biomarkers at different water availabilities. Lipid preservation was enhanced under low water-to-rock conditions across all fractions (Fig. 4). This effect was particularly visible at $240^{\circ} \mathrm{C}$, where up to $24.1 \mathrm{ppm}$ more unsaturated fatty acids and $4.8 \mathrm{ppm}$ more branched fatty acids were preferentially preserved at low water availabilities. Saturated fatty acids in particular displayed more preservation under low water-to-rock conditions, with up to 20.7 and $10.2 \mathrm{ppm}$ more preservation of the most common saturates, $16: 0$ and 18:0, respectively. The preservation of the EOP pattern was also more pronounced under low water-to-rock conditions.

\subsection{Clay-rich stream sample}

The clay-rich stream sample comprised a microbial mat over goethite and jarosite minerals in a lower abundance, but a similar relative abundance to that of the clay-poor stream sample. The clay-rich stream sample consisted of $40 \%$ quartz, $18 \%$ goethite, $6 \%$ jarosite, $25 \%$ illite, and $11 \%$ kaolinite (Table 1). 

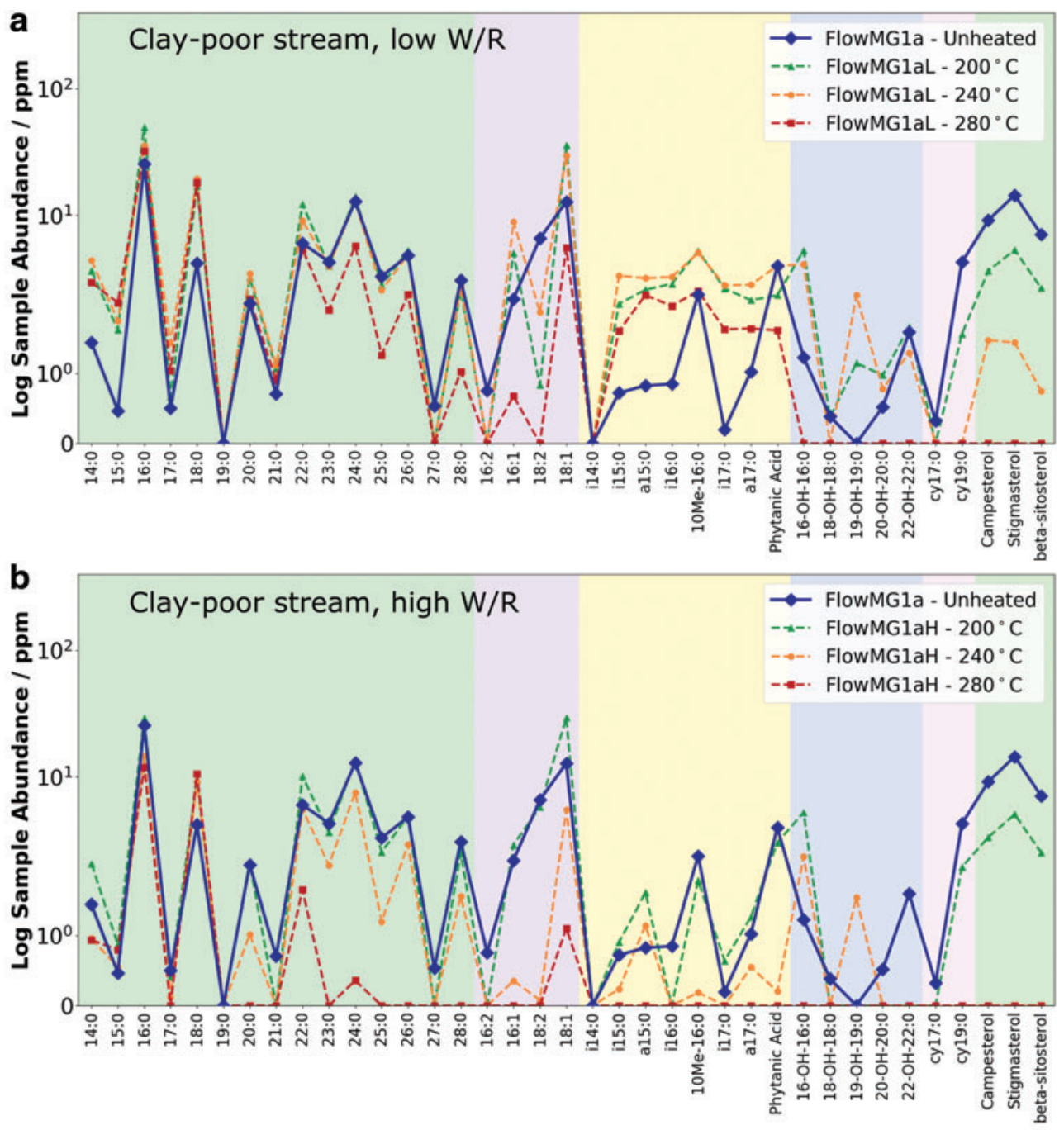

C
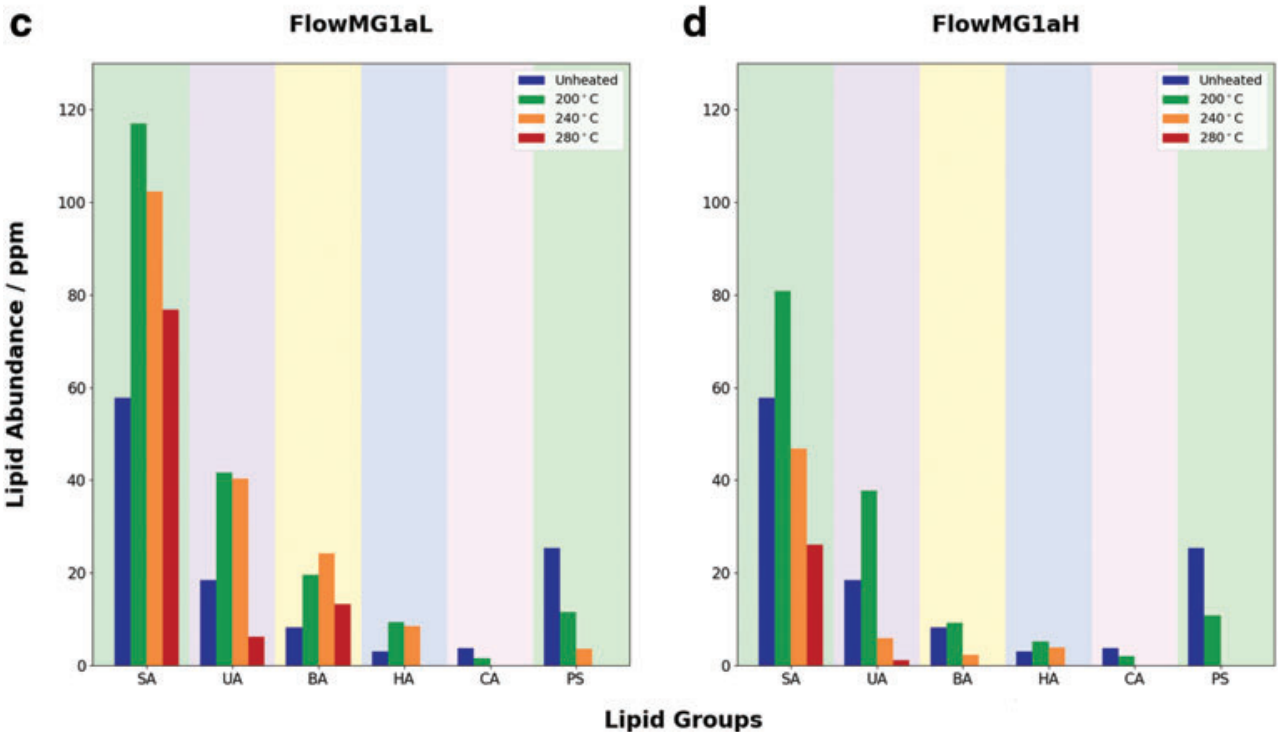

FIG. 3. Lipid abundances in pyrolyzed samples of (a) FlowMG1aL (clay-poor stream sample pyrolyzed at low water-torock ratios) and (b) FlowMG1aH (clay-poor stream sample pyrolyzed at high water-to-rock ratios). The solid line represents total lipid extracts of the unpyrolyzed clay-poor stream sample. The variation of the total lipid abundance per group of lipids is also presented for (c) FlowMG1aL and (d) FlowMG1aH. The lower abundances of all lipid groups under high water-torock ratios suggest that these conditions are less amenable to lipid preservation in these environments. BA, branched fatty acids; CA, cyclopropyl fatty acids; HA, hydroxy-fatty acids; PS, phytosterols; SA, saturated fatty acids; UA, unsaturated fatty acids; $\mathrm{W}: \mathrm{R}=$ water-to-rock ratio. Color images are available online. 


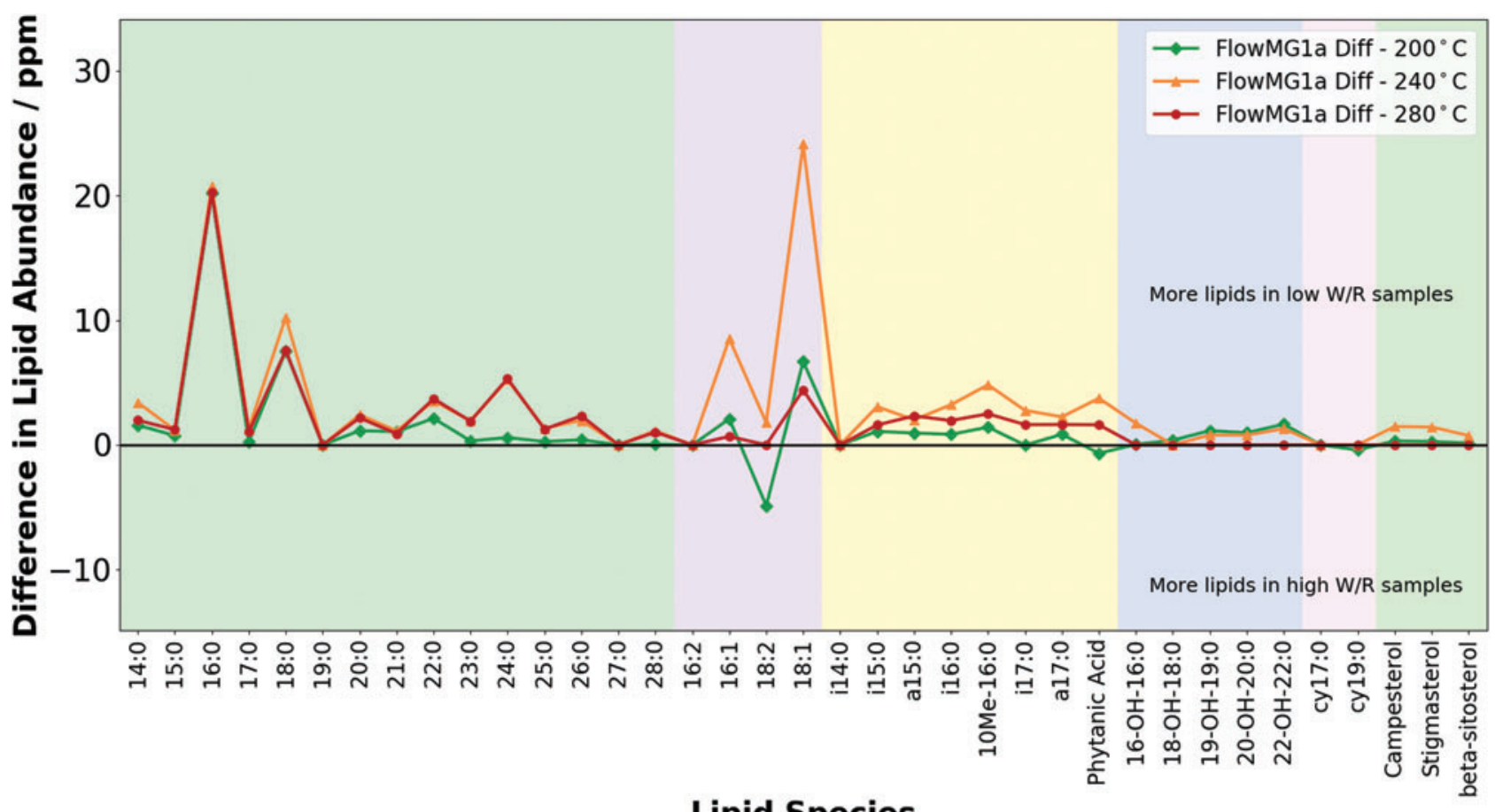

\section{Lipid Species}

FIG. 4. Comparison between the lipid abundances of FlowMG1a samples pyrolyzed at high and low water-to-rock ratios. A positive number indicates a higher abundance of lipids in FlowMG1aL, while a negative number indicates a higher abundance in FlowMG1aH. Color images are available online.

As observed in the clay-poor stream sample, lipid abundance and diversity decreased with increasing simulated maturation level; however, although the absolute abundance of lipids was greater in these clay-rich stream samples, the relative loss of lipids with each stepwise increase in maturation temperature appeared to be much greater across all lipid groups (Fig. 5a, b). Despite this, the biogenic EOP pattern was still retained. In addition, thiophenes were observed in the pyrolysates, which were neither observed in the total lipid extracts of the unpyrolyzed parent clay-poor and clay-rich stream samples, nor were they present in the pyrolysates of the postmaturation claypoor stream samples. Thiophenes are a group of organic molecules that contain a heterocyclic, five-membered planar ring that incorporates a sulfur molecule $\left(\mathrm{C}_{4} \mathrm{H}_{4} \mathrm{~S}\right)$. Three major species of thiophenes were identified: 3-methyl-2-(3,7,11-trimethyldodecyl) thiophene (Fig. 6I), 3-(4,8,12-trimethyltridecyl) thiophene (Fig. 6II), and methyl 9,12-epithio-9,11 octadecanoate (Fig. 6III). Thiophenes are observed to decrease in abundance with an increasing simulated maturation level, exhibiting a 25.6$30.6 \%$ loss in thiophene units from $200^{\circ} \mathrm{C}$ to $280^{\circ} \mathrm{C}$. Thiophene (III) was observed to be the most resistant to degradation, being the only thiophene species still present at $280^{\circ} \mathrm{C}$. The effect of simulated maturation on the cleavage of the adsorptive bonds between the fatty acids and the mineral substrate could still be observed but was less pronounced than in the clay-poor stream sample.

On average, $51.8 \%, 77.2 \%$, and $82.4 \%$ of saturated, unsaturated, and branched fatty acid species were lost during hydrous pyrolysis, respectively (Fig. 5c, d). These values were greater than those observed in the clay-poor stream sample, especially in the case of the unsaturated fraction, where up to $82.5 \%$ lipids were lost between $240^{\circ} \mathrm{C}$ and $280^{\circ} \mathrm{C}$. The sterols were also absent at temperatures greater than $200^{\circ} \mathrm{C}$.

The relationship between the effects of low and high water availability on lipid preservation was more uncertain in the clay-rich stream samples (Fig. 7). At $200^{\circ} \mathrm{C}$, there appeared to be no real advantage to high or low water availabilities, with a higher water-to-rock ratio slightly favoring the preservation of saturated and unsaturated fatty acids (1.07 and $4.35 \mathrm{ppm}$ more preservation in the high water-to-rock ratio experiments using the clay-rich stream sample, DryMJ1aH) but showing poor preservation of branched fatty acids $(47.1 \mathrm{ppm}$ more preservation in the low water-to-rock ratio experiments using the clay-rich stream sample, DryMJ1aL). However, the effect of low water availabilities on lipid preservation became clearer and more consistent between $240^{\circ} \mathrm{C}$ and $280^{\circ} \mathrm{C}$, with more thiophenes and saturated, unsaturated, and branched fatty acids extracted from DryMJ1aL.

\subsection{Survivability of saturated fatty acids as predicted by kinetic modeling}

The simulated maturation of organic compounds by hydrous pyrolysis allows for the unique opportunity to determine the kinetic parameters of the organic degradation reaction under a chosen set of conditions, in this case the water-to-rock ratio and mineralogy (Table 2). This can be done by considering the ratio of initial and final concentrations of a reactant after a period of time at a certain temperature. For the purposes of this model, the saturated 

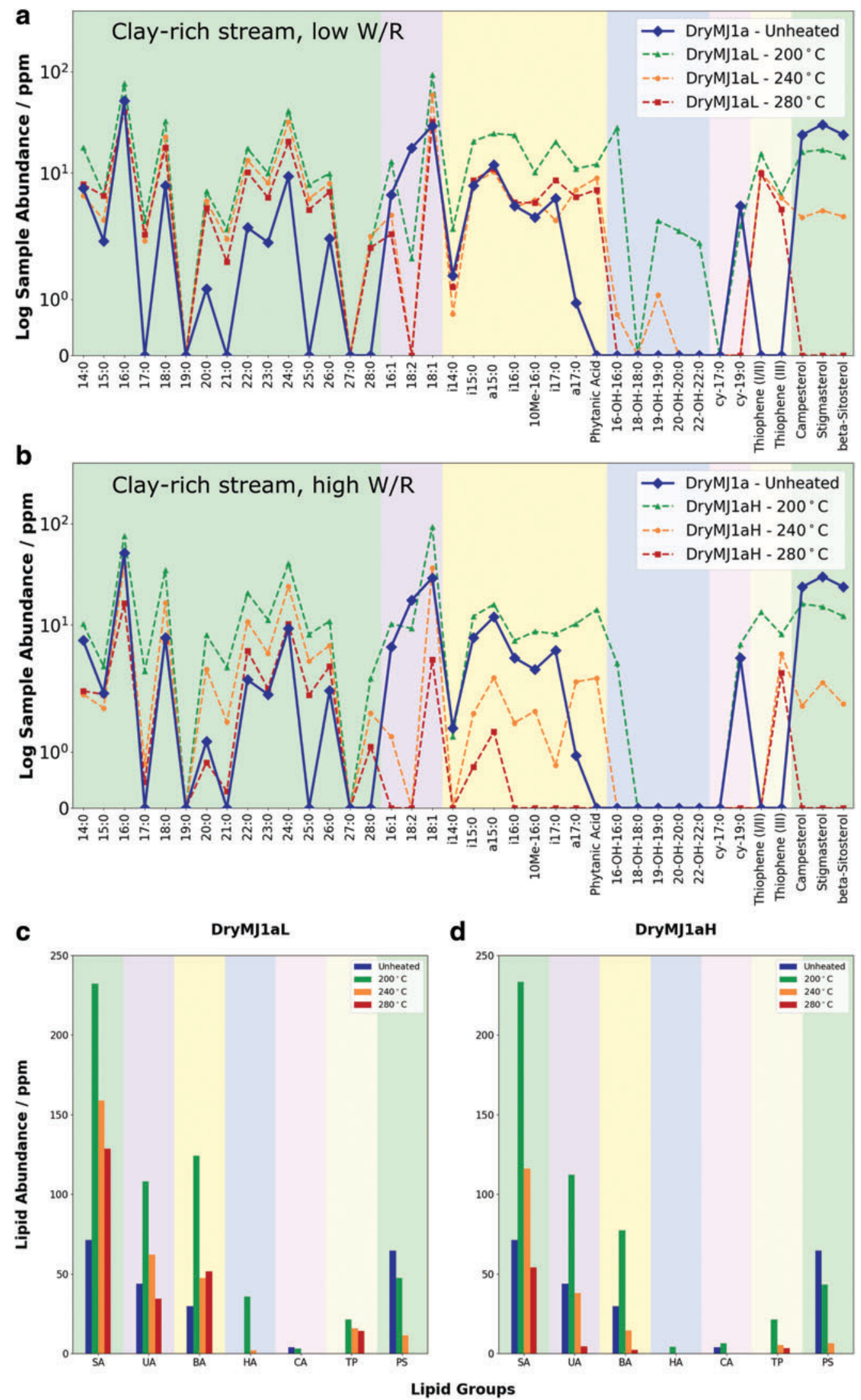

FIG. 5. Lipid abundances in pyrolyzed samples of (a) DryMJ1aL (clay-rich stream sample pyrolyzed at low water-to-rock ratio) and (b) DryMJ1aH (clay-rich stream sample pyrolyzed at high water-to-rock ratio). The solid line represents total lipid extracts of the unpyrolyzed DryMJ1a sample. The variation of the total lipid abundance per group of lipids is also presented for (c) DryMJ1aL and (d) DryMJ1aH. This figure uses the same naming scheme as found in Fig. 3. Color images are available online. 
I<smiles>Cc1ccsc1CCC(C)CCCC(C)CCCC(C)C</smiles>

II<smiles>CC(C)CCCC(C)CCCC(C)CCCc1ccsc1</smiles>

III

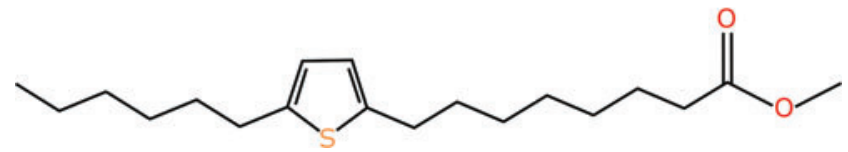

FIG. 6. Postderivatization thiophene species observed in the clay-rich stream samples. (I) and (II) are isoprenoidal thiophenes derived from chlorophyll, while (III) is likely to be an unsaturated fatty acid (18:2) that has incorporated inorganic sulfur into the functionalized lipid. Color images are available online.

fatty acids were chosen as the reactant, as these are the group of lipids that are the most resistant to degradation while still retaining easily recognizable biogenic characteristics. It was found that the kinetic behavior of the lipid degradation reaction can be approximated as a pseudo-first- order reaction under the studied conditions with a $95 \%$ confidence level for all samples analyzed (Fig. 8).

$$
\ln k=-\frac{E_{a}}{R}\left(\frac{1}{T}\right)+\ln A
$$

Key kinetic parameters such as the Arrhenius constant (A) and activation energy $\left(E_{a}\right)$ of the lipid degradation reaction were derived from the linear form of the Arrhenius equation (Eq. 2), where $k$ was the calculated rate constant. From these kinetic parameters, it was possible to model the loss in reactant over time by using a previously published method (Royle et al., 2018). The constraints of this model are also detailed in the literature, but in brief, the major assumptions of the model are that it assumes constant geothermal gradients, surface temperatures, and burial and exhumation rates, and assumes a closed system (no material inputs or outputs from the system), which is unlikely to occur in a natural environment. The modeling parameters for this system are as follows: a geothermal gradient of $0.008 \mathrm{~K} \cdot \mathrm{m}^{-1}$ characteristic of modern-day gradients on Mars (Hoffman, 2001), a maximum burial depth of $2 \mathrm{~km}$, and a burial rate of $10 \mathrm{~m} \cdot \mathrm{Ma}^{-1}$.

The modeling results are shown in Fig. 9. The diagram describes the degradation of lipids over geological time as a percentage of the total lipid content in each of the four separate environmental conditions studied. $t_{\max }$ is the time at which complete lipid degradation occurred in each of the models and allows us to quantify the degradative effects in each sample.

The model data suggested that the water-to-rock ratio and mineralogy did have a strong effect on lipid preservation in these sediments. In samples that were subjected to higher levels of simulated maturation by hydrous pyrolysis, it was found that samples with higher water-to-rock ratios experienced degradation at a rate almost two orders of magnitude

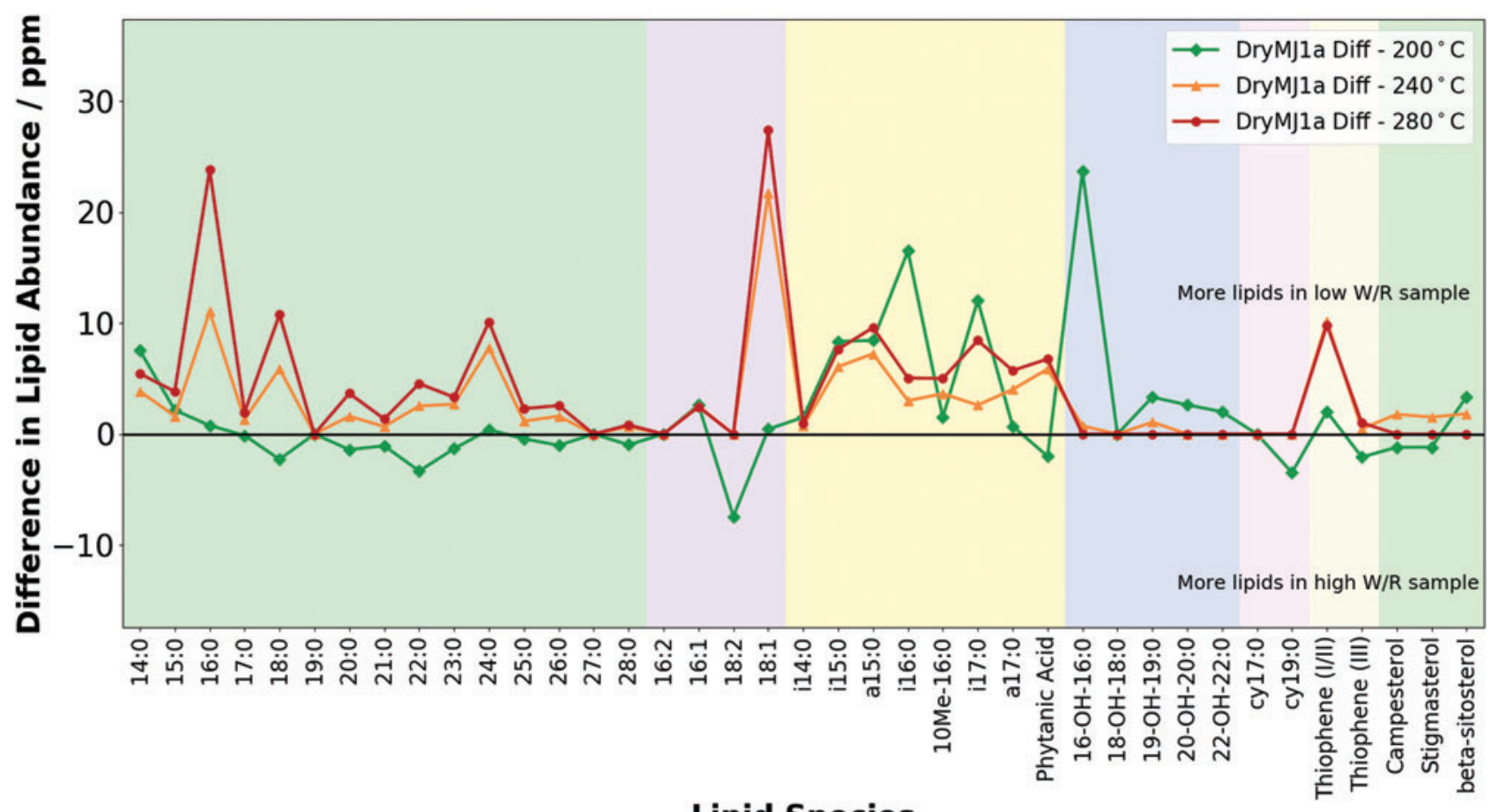

\section{Lipid Species}

FIG. 7. Comparison between the lipid abundances of clay-rich stream samples pyrolyzed at high and low water-to-rock ratios. A positive number indicates a higher abundance of lipids at lower water-to-rock ratios (DryMJ1aL), while a negative number indicates a higher abundance at higher water-to-rock ratios (DryMJ1aH). Color images are available online. 
Table 2. Data Used to Calculate the Kinetic Parameters Associated with Saturated Fatty Acid Degradation Under Varying Mineralogical and Water-to-Rock Conditions

\begin{tabular}{|c|c|c|c|c|c|c|}
\hline Sample code & $C_{0} / C_{T}$ & $k$ & $T(K)$ & $\ln k$ & $1 / T\left(K^{-1}\right)$ & ln $k$ error \\
\hline \multicolumn{7}{|c|}{ Clay-poor stream, low water-to-rock ratios } \\
\hline FlowMG1aL-200 ${ }^{\circ} \mathrm{C}$ & 1.114 & 0.00150 & 473 & -6.500 & 0.002114 & \pm 0.629 \\
\hline FlowMG1aL- $240^{\circ} \mathrm{C}$ & 1.263 & 0.00325 & 513 & -5.731 & 0.001949 & \pm 0.544 \\
\hline FlowMG1aL- $280^{\circ} \mathrm{C}$ & 1.698 & 0.00735 & 553 & -4.912 & 0.001808 & \pm 0.478 \\
\hline \multicolumn{7}{|c|}{ Clay-poor stream, high water-to-rock ratios } \\
\hline FlowMG1aH-200 ${ }^{\circ} \mathrm{C}$ & 1.615 & 0.00666 & 473 & -5.012 & 0.002114 & \pm 0.485 \\
\hline FlowMG1aH$-240^{\circ} \mathrm{C}$ & 2.788 & 0.01424 & 513 & -4.252 & 0.001949 & \pm 0.419 \\
\hline FlowMG1aH $-280^{\circ} \mathrm{C}$ & 4.998 & 0.02235 & 553 & -3.801 & 0.001808 & \pm 0.378 \\
\hline \multicolumn{7}{|c|}{ Clay-rich stream, low water-to-rock ratios } \\
\hline DryMJ1aL- $200^{\circ} \mathrm{C}$ & 1.484 & 0.00549 & 473 & -5.205 & 0.002114 & \pm 0.224 \\
\hline DryMJ1aL- $240^{\circ} \mathrm{C}$ & 2.981 & 0.01517 & 513 & -4.188 & 0.001949 & \pm 0.170 \\
\hline DryMJ1aL- $280^{\circ} \mathrm{C}$ & 6.414 & 0.02581 & 553 & -3.657 & 0.001808 & \pm 0.142 \\
\hline \multicolumn{7}{|c|}{ Clay-rich stream, high water-to-rock ratios } \\
\hline DryMJ1aH $-200^{\circ} \mathrm{C}$ & 1.491 & 0.00555 & 473 & -5.194 & 0.002114 & \pm 0.223 \\
\hline DryMJ $1 \mathrm{aH}-240^{\circ} \mathrm{C}$ & 2.183 & 0.01084 & 513 & -4.524 & 0.001949 & \pm 0.188 \\
\hline DryMJ1aH $-280^{\circ} \mathrm{C}$ & 2.694 & 0.01377 & 553 & -4.285 & 0.001808 & \pm 0.175 \\
\hline
\end{tabular}

$\mathrm{C}_{0} / \mathrm{C}_{\mathrm{T}}$ refers the ratio of initial and final concentrations of saturated fatty acids, $k$ refers to the rate constant as calculated from $\mathrm{C}_{0} / \mathrm{C}_{\mathrm{T}}$ assuming first-order reaction kinetics. Errors in $\ln \mathrm{k}$ are from instrument uncertainty.

faster than those observed in rocks with lower water-to-rock ratios. In addition, clay minerals were also shown to influence lipid preservation, with the clay-poor stream samples modeled to preserve lipids on timescales 5 to 10 times longer than those codeposited in the sediments from the clay-rich stream.

However, the primary observation was that despite ideal conditions for lipid preservation (surface temperature at
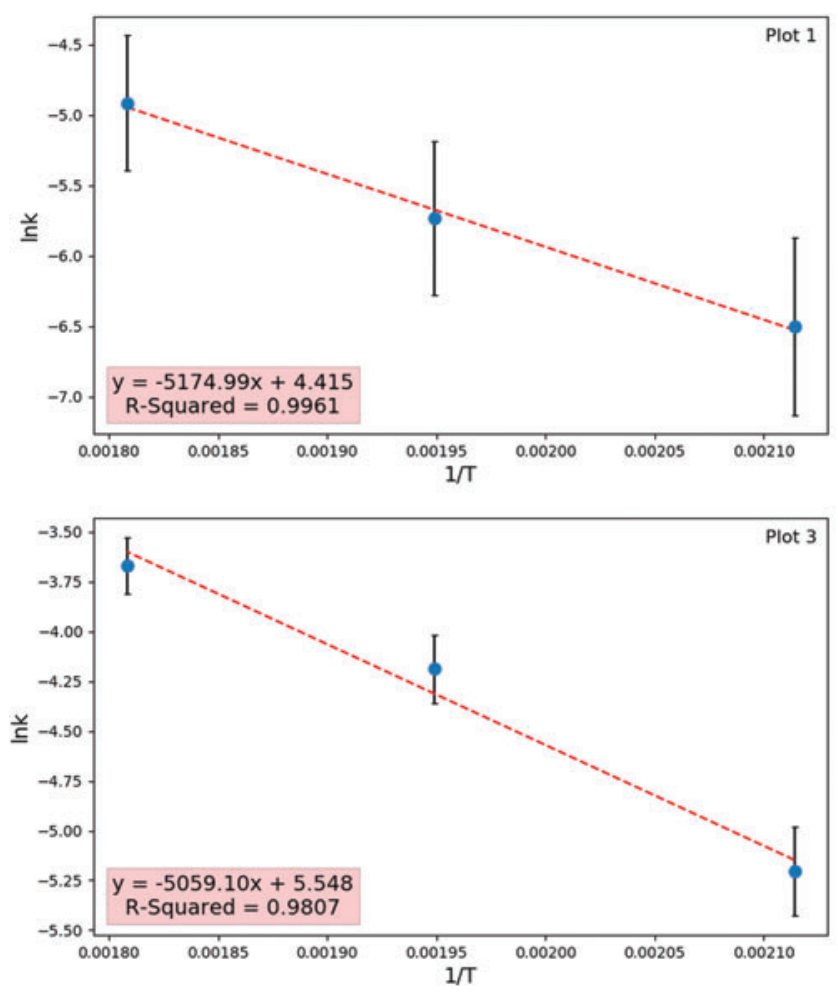

$-50^{\circ} \mathrm{C}$, low water-to-rock ratios, clay-poor mineralogy, and minimal burial), all saturated fatty acids were found be destroyed within $100 \mathrm{kA}$. In clay-rich samples modeled with similarly ideal conditions, all lipids were destroyed within $20 \mathrm{kA}$ of deposition, while in locations with high water-torock ratios, the lipids were not well preserved even on thousand-year timescales.
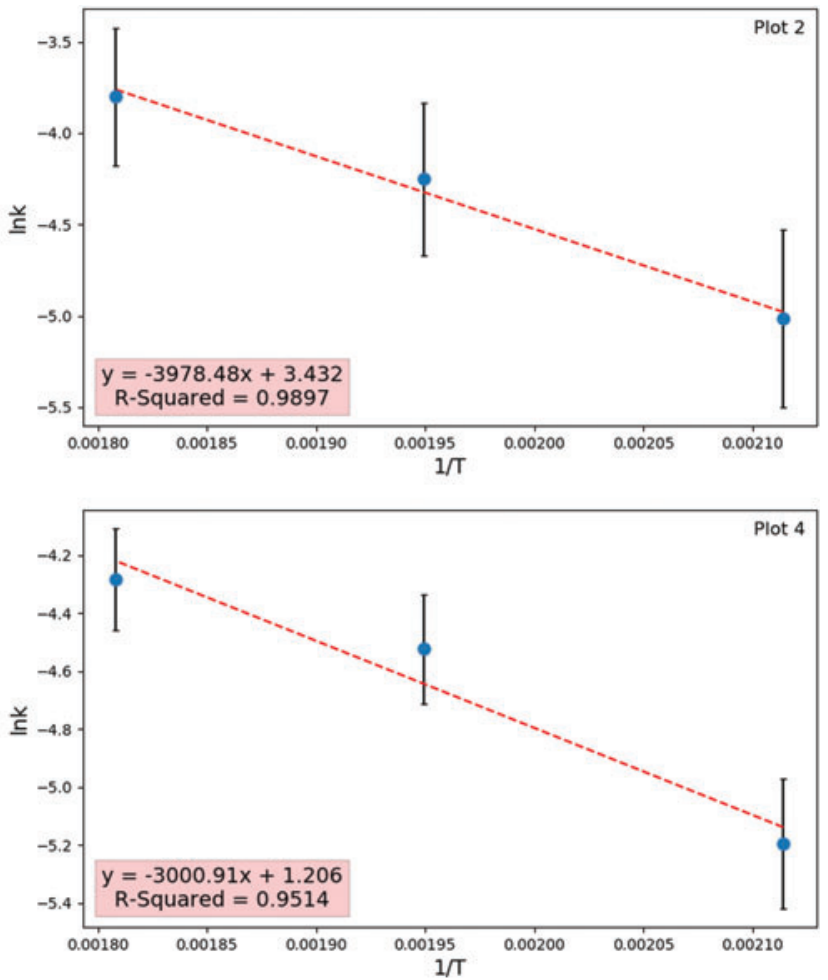

FIG. 8. Kinetic parameters as determined by the Arrhenius equation. That all the data points can be described with a linear trend with high confidence $($ alpha $=0.05)$ suggests that the pseudofirst-order approximation is valid for the lipid degradation reaction. Plot 1: Clay-poor stream sample at low water-to-rock ratios (FlowMG1aL); Plot 2: Clay-poor stream sample at high water-to-rock ratios (FlowMG1aH); Plot 3: Clay-rich stream sample at low water-to-rock ratios (DryMJ1aL); Plot 4: Clay-rich stream sample at high water-to-rock ratios (DryMJ1aH). Color images are available online. 


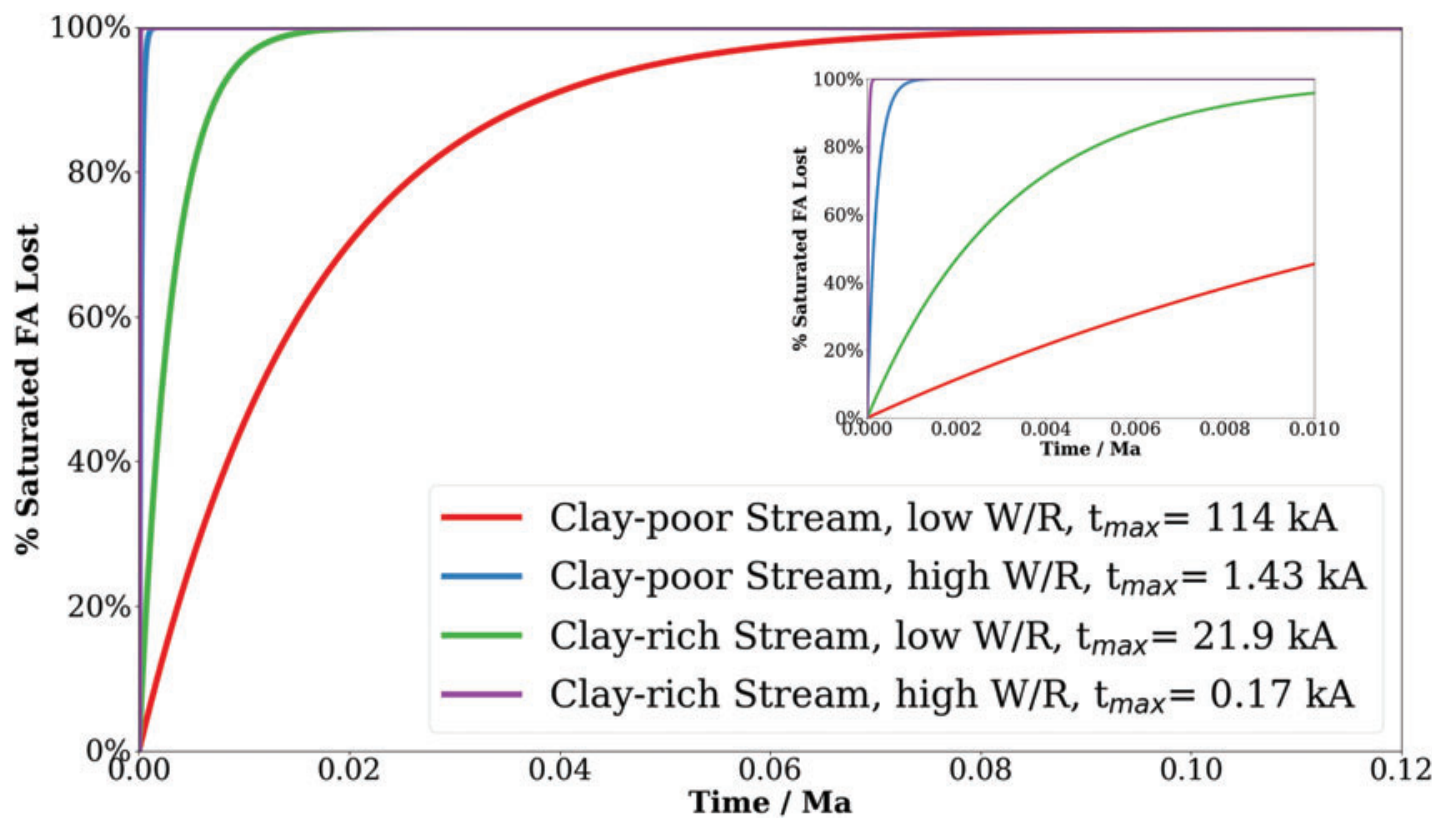

FIG. 9. Modeling results for the degradation of saturated fatty acids under martian conditions. High water-to-rock ratios are shown to exacerbate lipid degradation, as is a clay-rich mineralogy. However, even in the optimal preservation conditions, it is found that all saturated fatty acids are destroyed within $100 \mathrm{kA}$ of deposition. Inset: Models when run up to $0.01 \mathrm{Ma}$ show differences in degradation rates between high water-to-rock ratio samples. FA: fatty acids, $\mathrm{t}_{\text {max }}$ indicates the time at which all lipids are destroyed. Color images are available online.

\section{Discussion}

\subsection{Lipid biosignatures}

Our data suggest that although lipids are degraded during maturation, a significant proportion of the fatty acids, the core lipids of bacterial cell membranes, can survive longterm burial $(\sim 100 \mathrm{kA})$ and diagenesis in iron-rich, sulfur stream environments. The results were particularly promising in the clay-poor stream sample, where up to $58.9 \%$ of saturated fatty acids were still extractable after hydrous pyrolysis. Although the relative fatty acid yields of the clayrich stream samples were not as pronounced as in the claypoor stream, especially at the higher temperatures, up to $15.9 \%$ of saturated fatty acids were still extractable after being subjected to $280^{\circ} \mathrm{C}$ temperatures. Saturated fatty acids are thus the most promising solvent-soluble lipid biomarkers, being the most resilient to degradation during the diagenetic process and retaining their biogenic EOP pattern even at the latest stages of simulated diagenesis. At the same time, it was observed that the more structurally complex and hence more diagnostic biomarkers were more susceptible to degradation, as could be seen with the disappearance of the polycyclic terpene phytosteroids and cyclopropyl fatty acids. While phytosteroids are products of higher order plants and thus unlikely to have evolved on Mars, their response to simulated diagenesis can inform us of how compounds with similar structures, such as bacterial hopanoids, would respond under such conditions.

A greater abundance of fatty acids was observed in the pyrolysates than in the unpyrolyzed solvent extracts. A likely explanation for this phenomenon was that a significant proportion of fatty acids were adsorbed directly to the surface of the mineral substrate and could not be liberated by solvent extraction. However, hydrous pyrolysis may have resulted in the cleavage of these adsorptive bonds via hydrolysis, resulting in increased abundances of extractable organic matter in these postmaturation samples. Another possible explanation for the increase in fatty acids after the initial low-temperature maturation step is the cleavage of double bonds in unsaturated acids. We consider this unlikely, as such a mechanism should result in a relative increase in abundance of lower carbon-chain length acids. No evidence of this phenomenon was observed in the samples; rather, there was no change in relative responses for fatty acids of different chain lengths.

The mechanism by which the organic acids in the artificially matured samples are destroyed is likely to be an oxidative process involving organic/mineral interactions. While the simplest explanation for lipid degradation would be the decarboxylation of fatty acids to form complementary hydrocarbons, no alkanes were observed in any of the samples, suggesting that if this process was occurring, it was unlikely to be the primary mechanism of organic matter degradation. In contrast, goethite, jarosite, and smectite/illite clays were iron-bearing minerals ubiquitous in these samples and have the capability to completely oxidize organic matter to form water and carbon dioxide (Surdam and Crossey, 1985; Seewald, 2003); the low organic matter:mineral ratio of the stream samples may have exacerbated this effect. The role of oxidation in the loss of organic matter is corroborated by experiments that revealed that amorphous iron pyrolyzed in the presence of organic matter transformed into magnetite, indicating a reduction of ferric to ferrous iron, which must be balanced by the oxidation of the organic material present (Tan, pers. comm.). 


\subsection{Influences on lipid preservation}

The primary difference between the clay-poor and clayrich stream samples is the greater degree of degradation of lipids observed in the latter sample. We interpret this phenomenon as a consequence of the transformative effect of the clays present in the clay-rich stream sample. The catalytic effect of clays on organic matter breakdown is well known, especially with regard to the "cracking" of heavier macromolecular complexes into lighter hydrocarbons (e.g., Johns, 1979; Davis and Stanley, 1982; Espitalié et al., 1984; Tannenbaum and Kaplan, 1985). Ferric clays such as illite can also release $\mathrm{Fe}^{3+}$ during diagenesis that can contribute to oxidative degradation reactions (Surdam and Crossey, 1985), and thus may promote the accelerated destruction of fatty acids (Jurg and Eisma, 1964; Shimoyama and Johns, 1971). Even smectite clays that do not naturally contain ferric iron can hasten organic reactions via electron acceptors such as $\mathrm{Al}^{3+}$, generating highly reactive free radicals that catalyze various organic reactions (Solomon and Rosser, 1965; Solomon, 1968; Almon and Johns, 1975; Johns, 1979). While this can include preservation-enhancing reactions such as oxidative polymerization (Watson and Sephton, 2015), in these iron-rich environments, the primary reaction promoted by clay surfaces is the oxidation of organic matter by iron oxides.

Another factor that appears to have influenced the degradation of lipids in the sample was water availability: there were more extractable products in samples subjected to simulated maturation at low water-to-rock ratios than at high water-to-rock ratios. It is unclear how lower water-to-rock ratios result in reduced lipid destruction, but previous studies suggest that lower water to rock ratios heighten the protective effect of the mineral matrix in the pyrolysis process (Tannenbaum and Kaplan, 1985b; Koopmans et al., 1998). Another possibility could be that the lack of a liquid phase in the samples reduces the rate of the degradation reaction, or inhibits various reaction mechanisms that do not occur in dry environments, as water is a source of hydrogen and oxygen for certain organic reactions (Hoering, 1984; Stalker et al., 1994; Schimmelmann et al., 2001; Seewald, 2003).

\subsection{Thiophenes}

An interesting result of the simulated maturation experiments is the presence of thiophenes in the postmaturation extracts of the clay-rich stream samples. Thiophenes are particularly relevant to Mars due to their discovery in Gale Crater mudstones by evolved gas analysis with the Sample Analysis at Mars (SAM) instrument suite on the Curiosity rover (Eigenbrode et al., 2018). In terrestrial sediments, the source of the sulfur incorporated into these lipids is likely to be $\mathrm{H}_{2} \mathrm{~S}$ generated by the reduction of sulfate by SRB at temperatures $<100^{\circ} \mathrm{C}$ (Nissenbaum and Kaplan, 1972; Francois, 1987; Wakeham, 1995; Machel, 2001), although it can be produced by a variety of abiogenic processes (Kowalewski et al., 2010). Thiophenes are well known to form during the abiogenic incorporation of inorganic sulfur into specific functionalized lipid moieties, such as double bonds, in the early stages of diagenesis (Brassell et al., 1986; Vairavamurthy and Mopper, 1987; Sinninghe Damsté et al., 1988; Kohnen et al., 1989, 1990a; Sinninghe Damste et al., 1989; Kowalewski et al., 2010). Thiophenes are particularly useful as biosignatures as the incorporation of sulfur preserves the location of functional groups in the original carbon skeleton of the parent molecule (Sinninghe Damste et al., 1989; Kohnen et al., 1990b), and the positional information provided by thiophenes is preserved even following maturation (Koopmans et al., 1995). In addition, thiophenes are also more resistant to enzymatic degradation than their parent molecules, promoting their preservation in the rock record (Kohnen et al., 1990b). Thiophenes eventually form intramolecular poly- and monosulfide bonds that result in the formation of sulfur-rich high-molecular-weight organic macromolecules such as kerogens, which preserve information about the depositional environment and microbial communities hosted within (Brassell et al., 1986; Sinninghe Damste et al., 1989; Kohnen et al., 1990b; Sinninghe Damste and De Leeuw, 1990).

A key observation from the simulated maturation experiments is that thiophenes were only observed in the clay-rich stream sample, and not in the clay-poor stream sample. No thiophenes were observed in the unpyrolyzed samples, but this was to be expected as thiophenes and other compounds incorporated into insoluble macromolecular material are not liberated under the effects of solvent extraction. It is possible that the presence of clay minerals in the clay-rich stream samples promoted the breakdown of high-molecularweight organic sulfur compounds during artificial maturation, resulting in the liberation of sulfur-containing compounds such as thiophenes. The effect of clay minerals on the breakdown of kerogens has been the subject of previous studies. Kaolinite has been shown to increase the yield of pyrolysates during hydrous pyrolysis of kerogens (Eglinton et al., 1986), while illite has been observed to affect isomerization reactions of steranes and triterpenes (Tannenbaum et al., 1986), and enhance the breakdown of kerogen to form lighter hydrocarbons (Huizinga et al., 1987). Clay minerals in general have also been shown to promote the generation of organic acids from kerogen breakdown, and a similar process may be occurring for these thiophenes (Kawamura et al., 1986). The destructive effects of clay in our samples were potentially enhanced by the high clay/organic carbon ratios (Koopmans et al., 1998).

The isoprenoidal thiophenes (I and II) observed in the clay-rich stream samples are common in sediments, and are formed as diagenetic products of the incorporation of sulfur into diterpenoidal phytols derived from chlorophyll (e.g., Brassell et al., 1986; Kohnen et al., 1990b; Sinninghe Damste and De Leeuw, 1990). The origin of thiophenes in the clay-rich stream samples could come from two sources: (1) as analytical artifacts where the formation of thiophenes occurs at low temperatures by incorporation of sulfur into functionalized lipids, or (2) as indigenous units where simulated maturation leads to the liberation of thiophenes from high-molecular-weight compounds. We propose that the first option is unlikely, as previously conducted pyrolysis-GC-MS investigations of these samples revealed that thiophenes were present, implying the presence of kerogen-hosted thiophene units (Lewis et al., 2015, 2018). The isoprenoidal thiophenes observed following the simulated maturation process must thus be indigenous to the sample. Thiophene units are thought to be liberated from high-molecular-weight macromolecular fractions in two 
distinct stages: an initial low-temperature release at $180^{\circ} \mathrm{C}$ related to the breakdown of polysulfide bonds (S-S), followed by a secondary high-temperature release at $240^{\circ} \mathrm{C}$ and above related to the cleavage of monosulfide bonds $(\mathrm{C}-\mathrm{S})$ in high-molecular-weight compounds (Koopmans et al., 1995). Thus, the temperature at which thiophenes were liberated in the postmaturation extracts of our artificially matured samples may reveal how they are hosted in their organic parent network. The relatively low-temperature release of isoprenoidal thiophenes from DryMJ1a suggests the thermal breakdown of polysulfide bonds (S-S) in sulfur-rich highmolecular-weight fractions (low-temperature release), while the lack of a relatively high-temperature release implies the lack of monosulfide-bound thiophene units in the analyzed samples (Krein and Aizenshtat, 1994; Koopmans et al., 1995).

The other class of thiophene observed, methyl 9,12epithio-9,11 octadecanoate (thiophene III), was likely produced from the incorporation of sulfur into the -diene moiety present in the 18:2 fatty acid, which also explained the absence of the octadeca-9,12-dienoic acid in the pyrolysates (Sinninghe Damste et al., 1989; Kohnen et al., 1990b). The preservation of positional information even in the later stages of diagenesis of what would otherwise be labile functionalized lipids highlights the potential for thiophenes as biosignatures. However, the greater susceptibility of free compounds to degradation relative to those bound in a macromolecular organic network is well known in organic geochemistry; that these biomarkers are released during hydrous pyrolysis suggests that they might be then exposed to degradation.

\subsection{Implications for Mars exploration}

The solvent extracts of our postmaturation samples reveal the lipid biosignatures that may be expected to survive the later stages of diagenesis in sulfur stream systems on Mars. Although the relative abundance of organic compounds extracted varied across the samples, the overall response of different classes of organic compounds to simulated diagenesis was similar regardless of the mineralogy of the samples. More diagnostic biomarkers such as steroids and hopanoids are unlikely to survive the diagenetic process, limiting the ability to discern specific details about the microbial communities that produced any organic remains. In contrast, saturated fatty acids are the most resistant to the degradation process and can retain their biogenic EOP patterns, allowing them to be distinguished from abiotic sources of organic matter, such as meteoritic infall, and making them excellent targets for life detection missions to Mars.

Our experiments also suggest that the conditions most amenable for lipid preservation in sulfur streams are in water- and clay-poor environments. Paradoxically, these same conditions are less favorable for microbial communities that favor environments with high water availability. Previous work has shown that in addition to its preservative qualities, an ideal outcrop for life detection missions must also have high potential for habitability, as this would contribute to a greater abundance of fossilized organic matter that may survive diagenesis (Tan et al., 2018). Fortunately, several locations of astrobiological interest on
Mars feature low water availability, and for which acidic, saline, and iron- and sulfur-rich environments are appropriate geochemical analogues. Meridiani Planum is an outcrop with sediments rich in hematite and jarosite, was likely an interdune deposit or a playa lake with a fluctuating water table, and represents one of the more favorable locations for surface biology during the Hesperian period of martian history (Squyres and Knoll, 2005). Geochemical analyses of Meridiani Planum suggest that the outcrop was arid, comparable with that of terrestrial evaporite deposits (Squyres et al., 2004; Knoll et al., 2005; Tosca et al., 2005, 2008). The mineralogy and geochemistry of Meridiani Planum are very similar to that of the two studied iron- and sulfur-rich acid streams, with some theories suggesting a similar mode of formation between the two (Zolotov and Shock, 2005). The surface environments would have become progressively colder and more arid over geological time (Richardson and Mischna, 2005; Shuster and Weiss, 2005). While Meridiani Planum cannot be considered representative of the entirety of the martian surface environment, there is evidence to suggest that much of Mars was subject to similar conditions, for example, the Sheepbed mudstones at Gale Crater are posited to have been deposited in a low-temperature, low water activity system (McLennan et al., 2014; Bristow et al., 2015). Thus, low water activity, iron-oxide-rich environments that could have supported biological activity may present an attractive balance in terms of habitability and biomass generation and preservative qualities for biosignatures on Mars.

Clay content is another factor that influences lipid preservation in these sediments. Clays are common minerals on Mars and are generally the products of aqueous alteration of olivines and other basaltic minerals (Poulet et al., 2005; Milliken and Bish, 2010). Clay formation on Mars occurred primarily in the Noachian, but may have extended into the early Hesperian (Bibring et al., 2006; Milliken and Bish, 2010; Ehlmann et al., 2011; Vaniman et al., 2014). While clays are generally considered advantageous for organic matter preservation due to their ability to sorb and thus concentrate and sequester organic matter into macromolecular kerogen (e.g., Keil et al., 1994; Hedges and Keil, 1995; Farmer and Des Marais, 1999; Salmon et al., 2000), our results suggest that clays are deleterious in these iron-rich environments due to their ability to promote oxidation reactions between organic matter and iron-bearing minerals such as jarosite, goethite, and smectite/illite. As clays are known to cause decarboxylation and thus result in $n$-alkane formation (Shimoyama and Johns, 1971; Almon and Johns, 1975; Johns, 1979), the lack of $n$-alkanes in our samples must be the result of further oxidation by iron-bearing minerals.

While this report does not propose a specific mechanism for these oxidative reactions, preliminary results from artificial maturation experiments of the clay-poor stream sample mixed with the noniron-bearing clay montmorillonite show similar levels of degradation to the clay-rich stream in this study (Tan, pers. comm.). Hence, it is unlikely that $\mathrm{Fe}^{3+}$ in the clay structure of iron-bearing clays is specifically the cause for increased degradation in these samples; rather, it is the mineralogical interactions between organic matter, clay, and highly oxidizing iron minerals that cause heightened rates of degradation. 


\subsection{Implications of kinetic modeling}

With conditions on Mars being most habitable in the distant past and the preservation of the organic remains of life being enhanced by burial, we investigated the kinetics of organic degradation in the subsurface of Mars. Models derived from the reaction kinetics support the interpretation that water- and clay-poor sulfur stream environments are the conditions that are most suitable for lipid preservation (specifically the saturated fatty acid fraction). However, despite optimal conditions, the model data predict that solventextractable saturated fatty acids will not survive over geological time, surviving only up to $100 \mathrm{kA}$ after deposition and burial. Considering that the Amazonian period of Mars' history is widely considered to be relatively unlikely to support life given the low water availability, highly oxidizing surface environment, high salinity, and high incidence of ionizing radiation in the present day (e.g., McKay and Davis, 1991; Hecht et al., 2009; Hassler et al., 2014), and that the latest period of likely widespread martian habitability was $3 \mathrm{Ga}$ ago (Cockell, 2014; Westall et al., 2015), our data would suggest that these fossil sulfur stream environments would lose their solvent soluble records of life on Mars if buried and exposed to moderate temperatures and pressures over martian geological time. At the same time, if solvent-extractable organic matter was found in sulfur stream environments on Mars, our models would suggest that the biological communities that formed these fatty acids must have lived less than $100 \mathrm{kA}$ ago. Our findings provide a possible reason for why organic evidence of past life has not been found in the martian environments tested to date.

Although the models paint a bleak picture for the detection of soluble organic matter via wet chemistry techniques, it should be noted that iron on Mars may not be as widespread as previously thought, with CheMin instrumental mineralogy data on the Mars Science Laboratory (MSL) Curiosity Rover showing that hematite is relatively sparse in most mudstone samples (e.g., Bish et al., 2013; Vaniman et al., 2014; Treiman et al., 2016; Rampe et al., 2017; Morris et al., 2019). While our data cannot be extrapolated to mineral compositions of different iron abundances, it is possible that lower relative abundances of iron oxidants may contribute to improved lipid preservation. Nevertheless, in the search for life on Mars in Noachian and Hesperian rocks, it appears that the absence of evidence is by no means evidence of absence, but simply the possible chemical consequence of long-term storage on the surface of Mars.

It is important to note that the models have several inbuilt assumptions to them that may increase or decrease the expected amount of surviving lipids. For example, the assumption that the experiment is a closed system would suggest that natural samples would contain a lesser amount of lipids due to external aqueous activity flushing out free fatty acids, or their destruction due to cosmic rays. In addition, close-system experimentation precludes any open-system processes associated with the postdepositional redistribution, transport, and subsequent potential preservation of organic matter by various mechanisms such as hydrothermal fluids; these processes were significant on the early Earth, and were possibly equally significant on Mars (e.g., Duda et al., 2018).

In contrast, an important caveat of these models is that they only predict the amount of detectable solvent-extractable or- ganic matter remaining in a sample after a certain period. As revealed in the literature (Eigenbrode et al., 2018), it is known that macromolecular organic matter can survive the radiative and diagenetic conditions of martian geological history (although it is important to note that the age of this material is not yet known). Macromolecular organic matter is not solvent extractable and thus was not considered by these sets of models. The model also does not provide insights into whether the remaining organic matter can be distinguished from sources of abiotic carbon, such as meteoritic material (Chyba and Sagan, 1992; Summons et al., 2008; Sephton, 2012) or Fischer/ Tropsch-type (FTT) reactions (McCollom and Seewald, 2006; Mißbach et al., 2018). The latter is especially important, as FTT reactions are a common occurrence in hydrothermal deposits (McCollom and Seewald, 2007; Konn et al., 2015) and can produce long-chain saturated fatty acids (Mißbach et al., 2018). Finally, the model does not consider the effects of minerals common to the surface of Mars that are not present in our analog samples, most egregiously the presence of perchlorates in the martian regolith (Carrier and Kounaves, 2015). While we acknowledge the importance of perchlorate minerals, and the complexity of perchlorate mineral interactions with organic matter (Góbi et al., 2017; Fornaro et al., 2018), postulating how it may affect the kinetics of organic matter preservation in the studied environments is beyond the scope of this study.

\section{Conclusions}

The late Noachian and early Hesperian represented habitable conditions on Mars contemporaneous with the emergence of life on Earth. We can develop our suite of life detection skills by examining analog sites on Earth that are chemically and possibly biologically similar to the late Noachian and early Hesperian of Mars. Acid iron- and sulfur-rich streams and the microbial communities hosted within these environments provide one such analog site. Rocks representing the late Noachian and early Hesperian of Mars are old and any organic matter within would have been stored for billions of years. Samples that are likely to contain evidence of past life on Mars must exhibit conditions that promote the preservation of organic biomarkers over geological time.

Artificial maturation techniques can recreate the effects of geological storage on Mars in Earth laboratories and allow us to draw conclusions about the behavior of organic biomarkers in response to diagenesis in these distinct geochemical environments. Fatty acids are found to be persistent organic biomarkers, but complex organic structures are susceptible to degradation. During maturation, thiophenes are released at low temperatures and fatty acids are liberated from adsorption sites. Low carbon contents, high water-to-rock ratios, and the presence of iron-rich clay minerals are all conditions that decrease the preservation of organic biomarkers in iron- and sulfur-rich stream environments. Kinetic modeling derived from quantitative hydrous pyrolysis, however, suggests that these conditions are applicable only on a $100 \mathrm{kA}$ timescale, after which all solvent-extractable organic matter is expected to be lost.

The analysis of kinetic parameters predicts that regardless of the carbon content, water availability, and the presence of 
clay minerals, saturated fatty acids are not expected to be detectable by wet chemistry techniques following postburial diagenesis. Sample selection on future Mars missions should appreciate that some samples, which reflect habitable conditions on Mars, can inhibit the preservation of martian organic matter when exposed to geological storage over billions of years. Sample selection strategies must therefore consider the pre-, syn-, and postburial histories of habitable conditions on Mars and the balance between the production of biomass and the long-term preservation of organic biomarkers over geological time.

\section{Acknowledgment}

Code used for kinetic parameter modeling is freely available at: https://github.com/ImperialCollegeLondon/ArrheniusModel/ blob/master/ChloronapthaleneModellingWork.py

\section{Author Disclosure Statement}

No competing financial interests exist.

\section{Funding Information}

This work was supported by UK Space Agency grant ST/ N000560/1 and an Imperial College President's PhD scholarship granted to J.T.

\section{References}

Almon, W.R. and Johns, W.D. (1975) Petroleum forming reactions: the mechanism and rate of clay catalyzed fatty acid decarboxylation. In Advances in Organic Geochemistry, edited by R. Campos and J. Goni, pp 155-177, Empresa Nacional Adar. de investigaciones Mineras, Madrid, Spain.

Aubrey, A., Cleaves, H.J., Chalmers, J.H., Skelley, A.M., Mathies, R.A., Grunthaner, F.J., Ehrenfreund, P., and Bada, J.L. (2006) Sulfate minerals and organic compounds on Mars. Geology 34:357-360.

Benison, K.C. and Bowen, B.B. (2006) Acid saline lake systems give clues about past environments and the search for life on Mars. Icarus 183:225-229.

Bibring, J.-P., Langevin, Y., Mustard, J.F., Poulet, F., Arvidson, Raymond, Gendrin, A., Gondet, B., Mangold, N., Pinet, P., Forget, F., Berthé, M., Bibring, J.-P., Gendrin, A., Gomez, C., Gondet, B., Jouglet, D., Poulet, F., Soufflot, A., Vincendon, M., Combes, M., Drossart, P., Encrenaz, T., Fouchet, T., Merchiorri, R., Belluci, G., Altieri, F., Formisano, V., Capaccioni, F., Cerroni, P., Coradini, A., Fonti, S., Korablev, O., Kottsov, V., Ignatiev, N., Moroz, V., Titov, D., Zasova, L., Loiseau, D., Mangold, N., Pinet, Patrick, Douté, S., Schmitt, B., Sotin, C., Hauber, E., Hoffmann, H., Jaumann, R., Keller, U., Arvidson, Ray, Mustard, J.F., Duxbury, T., Forget, F., and Neukum, G. (2006) Global mineralogical and aqueous mars history derived from OMEGA/Mars express data. Science 312:400-404.

Bish, D.L., Blake, D.F., Vaniman, D.T., Chipera, S.J., Morris, R.V., Ming, D.W., Treiman, A.H., Sarrazin, P., Morrison, S.M., Downs, R.T., Achilles, C.N., Yen, A.S., Bristow, T.F., Crisp, J., Morookian, J.M., Farmer, J.D., Rampe, E.B., Stolper, E.M., and Spanovich, N.; MSL Science Team. (2013) Xray diffraction results from Mars Science Laboratory: mineralogy of Rocknest at Gale Crater. Science 341:1238932.

Borlina, C.S., Ehlmann, B.L., and Kite, E.S. (2015) Modeling the thermal and physical evolution of Mount Sharp's sedi- mentary rocks, Gale Crater, Mars: implications for diagenesis on the MSL Curiosity rover traverse. J Geophys Res Planets 120:1396-1414.

Brassell, S.C., Lewis, C.A., de Leeuw, J.W., de Lange, F., and Damsté, J.S.S. (1986) Isoprenoid thiophenes: novel products of sediment diagenesis? Nature 320:160-162.

Bristow, T.F., Bish, D.L., Vaniman, D.T., Morris, R.V., Blake, D.F., Grotzinger, J.P., Rampe, E.B., Crisp, J.A., Achilles, C.N., Ming, D.W., Ehlmann, B.L., King, P.L., Bridges, J.C., Eigenbrode, J.L., Sumner, D.Y., Chipera, S.J., Moorokian, J.M., Treiman, A.H., Morrison, S.M., Downs, R.T., Farmer, J.D., Des Marais, D., Sarrazin, P., Floyd, M.M., Mischna, M.A., and McAdam, A.C. (2015) The origin and implications of clay minerals from Yellowknife Bay, Gale crater. Mars Am Mineral 100:824-836.

Carrier, B.L. and Kounaves, S.P. (2015) The origins of perchlorate in the Martian soil. Geophys Res Lett 42:3739-3745.

Caswell, T.E. and Milliken, R.E. (2017) Evidence for hydraulic fracturing at Gale crater, Mars: implications for burial depth of the Yellowknife Bay formation. Earth Planet Sci Lett 468 : $72-84$.

Chyba, C. and Sagan, C. (1992) Endogenous production, exogenous delivery and impact-shock synthesis of organic molecules: an inventory for the origins of life. Nature 355: 125-132.

Cockell, C.S. (2000) The ultraviolet environment of mars: biological implications past, present, and future. Icarus 146:343-359.

Cockell, C.S. (2014) Trajectories of martian habitability. Astrobiology 14:182-203.

Dartnell, L.R. (2011) Ionizing radiation and life. Astrobiology 11:551-582.

Davis, J.B. and Stanley, J.P. (1982) Catalytic effect of smectite clays in hydrocarbon generation revealed by pyrolysis-gas chromatography. J Anal Appl Pyrolysis 4:227-240.

Duda, J.-P., Schäfer, N., Reitner, J., Van Kranendonk, M.J., Mißbach, H., Thiel, V., Reinhardt, M., and Bauersachs, T. (2018) Ideas and perspectives: hydrothermally driven redistribution and sequestration of early Archaean biomass - the "hydrothermal pump hypothesis." Biogeosciences 15:1535-1548.

Edgett, K.S., Schieber, J., Grotzinger, J.P., Siebach, K.L., Stack, K.M., Edgar, L.A., Gasda, P.J., Frydenvang, J., Gupta, S., Kronyak, R.E., and Kah, L.C. (2016) Depth of burial for lithification and diagenesis of muds and sands on early Mars. In SEPM/AAPG Hedberg Research Conference. Santa Fe, New Mexico, pp 1-4.

Eglinton, T.I. and Douglas, A.G. (1988) Quantitative study of biomarker hydrocarbons released from Kerogens during hydrous pyrolysis. Energy Fuels 2:81-88.

Eglinton, T.I., Rowland, S.J., Curtis, C.D., and Douglas, A.G. (1986) Kerogen-mineral reactions at raised temperatures in the presence of water. Org Geochem 10:1041-1052.

Ehlmann, B.L., Mustard, J.F., Murchie, S.L., Bibring, J.-P., Meunier, A., Fraeman, A.A., and Langevin, Y. (2011) Subsurface water and clay mineral formation during the early history of Mars. Nature 479:53-60.

Eigenbrode, J.L., Summons, R.E., Steele, A., Freissinet, C., Millan, M., Navarro-González, R., Sutter, B., Mcadam, A.C., Conrad, P.G., Hurowitz, J.A., Grotzinger, J.P., and Gupta, S. (2018) Organic matter preserved in 3-billion-year-old mudstones at Gale crater, Mars. Science 360:1096-1101.

Espitalié, J., Senga Makadi, K., and Trichet, J. (1984) Role of the mineral matrix during kerogen pyrolysis. Org Geochem 6: $365-382$. 
Farley, K.A., Malespin, C., Mahaffy, P., Grotzinger, J.P., Vasconcelos, P.M., Milliken, R.E., Malin, M., Edgett, K.S., Pavlov, A.A., Hurowitz, J.A., Grant, J.A., Miller, H.B., Arvidson, R., Beegle, L., Calef, F., Conrad, P.G., Dietrich, W.E., Eigenbrode, J., Gellert, R., Gupta, S., Hamilton, V., Hassler, D.M., Lewis, K.W., McLennan, S.M., Ming, D., Navarro-González, R., Schwenzer, S.P., Steele, A., Stolper, E.M., Sumner, D.Y., Vaniman, D., Vasavada, A., Williford, K., Wimmer-Schweingruber, R.F., Blake, D.F., Bristow, T., DesMarais, D., Edwards, L., Haberle, R., Hoehler, T., Hollingsworth, J., Kahre, M., Keely, L., McKay, C., Wilhelm, M.B., Bleacher, L., Brinckerhoff, W., Choi, D., Dworkin, J.P., Floyd, M., Freissinet, C., Garvin, J., Glavin, D., Harpold, D., Martin, D.K., McAdam, A., Raaen, E., Smith, M.D., Stern, J., Tan, F., Trainer, M., Meyer, M., Posner, A., Voytek, M., Anderson, R.C.R.B., Aubrey, A., Behar, A., Blaney, D., Brinza, D., Christensen, L., Crisp, J.A., DeFlores, L., Feldman, J., Feldman, S., Flesch, G., Hurowitz, J.A., Jun, I., Keymeulen, D., Maki, J., Mischna, M., Morookian, J.M., Parker, T., Pavri, B., Schoppers, M., Sengstacken, A., Simmonds, J.J., Spanovich, N., Juarez, M.D.L.T., Webster, C.R., Yen, A., Archer, P.D., Cucinotta, F., Jones, J.H., Morris, R.V., Niles, P., Rampe, E., Nolan, T., Fisk, M., Radziemski, L., Barraclough, B., Bender, S., Berman, D., Dobrea, E.N., Tokar, R., Williams, R.M.E., Yingst, A., Leshin, L., Cleghorn, T., Huntress, W., Manhès, G., Hudgins, J., Olson, T., Stewart, N., Sarrazin, P., Vicenzi, E., Wilson, S.A., Bullock, M., Ehresmann, B., Peterson, J., Rafkin, S., Zeitlin, C., Fedosov, F., Golovin, D., Karpushkina, N., Kozyrev, A., Litvak, M., Malakhov, A., Mitrofanov, I., Mokrousov, M., Nikiforov, S., Prokhorov, V., Sanin, A., Tretyakov, V., Varenikov, A., Vostrukhin, A., Kuzmin, R., Clark, B., Wolff, M., Botta, O., Drake, D., Bean, K., Lemmon, M., Anderson, R.C.R.B., Herkenhoff, K., Lee, E.M., Sucharski, R., Hernández, M.Á.D.P., Ávalos, J.J.B., Ramos, M., Kim, M.-H., Plante, I., Muller, J.-P., Ewing, R., Boynton, W., Downs, R., Fitzgibbon, M., Harshman, K., Morrison, S., Kortmann, O., Palucis, M., Williams, A., Lugmair, G., Wilson, M.A., Rubin, D., Jakosky, B., Balic-Zunic, T., Frydenvang, J., Jensen, J.K., Kinch, K., Koefoed, A., Madsen, M.B., Stipp, S.L.S., Boyd, N., Campbell, J.L., Perrett, G., Pradler, I., VanBommel, S., Jacob, S., Owen, T., Rowland, S., Savijärvi, H., Boehm, E., Böttcher, S., Burmeister, S., Guo, J., Köhler, J., García, C.M., Mueller-Mellin, R., Bridges, J.C., McConnochie, T., Benna, M., Franz, H., Bower, H., Brunner, A., Blau, H., Boucher, T., Carmosino, M., Atreya, S., Elliott, H., Halleaux, D., Rennó, N., Wong, M., Pepin, R., Elliott, B., Spray, J., Thompson, L., Gordon, S., Newsom, H., Ollila, A., Williams, J., Bentz, J., Nealson, K., Popa, R., Kah, L.C., Moersch, J., Tate, C., Day, M., Kocurek, G., Hallet, B., Sletten, R., Francis, R., McCullough, E., Cloutis, E., Kate, I.L., Ten Fraeman, A., Scholes, D., Slavney, S., Stein, T., Ward, J., Berger, J., and Moores, J.E. (2014) In situ radiometric and exposure age dating of the martian surface. Science 24:1247166.

Farmer, J.D. and Des Marais, D.J. (1999) Exploring for a record of ancient Martian life. J Geophys Res Planets 104:26977-26995.

Fernández-Remolar, D.C. (2003) Geological record of an acidic environment driven by iron hydrochemistry: the Tinto River system. J Geophys Res 108:5080.

Fornaro, T., Steele, A., and Brucato, J. (2018) Catalytic/protective properties of martian minerals and implications for possible origin of life on Mars. Life 8:56.

Francois, R. (1987) A study of sulfur enrichment in the humic fraction of marine sediments during early diagenesis. Geochim Cosmochim Acta 51:17-27.
Gendrin, A., Mangold, N., Bibring, J.-P., Langevin, Y., Gondet, B., Poulet, F., Bonello, G., Quantin, C., Mustard, J., Arvidson, R., and LeMouélic, S. (2005) Sulfates in Martian layered terrains: the OMEGA/Mars Express view. Science 307:1587-1591.

Góbi, S., Bergantini, A., and Kaiser, R.I. (2017) Degradation of adenine on the martian surface in the presence of perchlorates and ionizing radiation: a reflectron time-of-flight mass spectrometric study. Astrophys $J$ 838:84.

Hassler, D.M., Zeitlin, C., Wimmer-Schweingruber, R.F., Ehresmann, B., Rafkin, S., Eigenbrode, J.L., Brinza, D.E., Weigle, G., Bottcher, S., Bohm, E., Burmeister, S., Guo, J., Kohler, J., Martin, C., Reitz, G., Cucinotta, F.A., Kim, M.-H., Grinspoon, D., Bullock, M.A., Posner, A., Gomez-Elvira, J., Vasavada, A., Grotzinger, J.P., Team, M.S., Kemppinen, O., Cremers, D., Bell, J.F., Edgar, L., Farmer, J., Godber, A., Wadhwa, M., Wellington, D., McEwan, I., Newman, C., Richardson, M., Charpentier, A., Peret, L., King, P., Blank, J., Schmidt, M., Li, S., Milliken, R., Robertson, K., Sun, V., Baker, M., Edwards, C., Ehlmann, B., Farley, K., Griffes, J., Miller, H., Newcombe, M., Pilorget, C., Rice, M., Siebach, K., Stack, K., Stolper, E., Brunet, C., Hipkin, V., Leveille, R., Marchand, G., Sanchez, P.S., Favot, L., Cody, G., Steele, A., Fluckiger, L., Lees, D., Nefian, A., Martin, M., Gailhanou, M., Westall, F., Israel, G., Agard, C., Baroukh, J., Donny, C., Gaboriaud, A., Guillemot, P., Lafaille, V., Lorigny, E., Paillet, A., Perez, R., Saccoccio, M., Yana, C., ArmiensAparicio, C., Rodriguez, J.C., Blazquez, I.C., Gomez, F.G., Hettrich, S., Malvitte, A.L., Jimenez, M.M., Martinez-Frias, J., Martin-Soler, J., Martin-Torres, F.J., Jurado, A.M., MoraSotomayor, L., Caro, G.M., Lopez, S.N., Peinado-Gonzalez, V., Pla-Garcia, J., Manfredi, J.A.R., Romeral-Planello, J.J., Fuentes, S.A.S., Martinez, E.S., Redondo, J.T., UrquiO’Callaghan, R., Mier, M.-P.Z., Chipera, S., Lacour, J.-L., Mauchien, P., Sirven, J.-B., Manning, H., Fairen, A., Hayes, A., Joseph, J., Squyres, S., Sullivan, R., Thomas, P., Dupont, A., Lundberg, A., Melikechi, N., Mezzacappa, A., Berger, T., Matthia, D., Prats, B., Atlaskin, E., Genzer, M., Harri, A.-M., Haukka, H., Kahanpaa, H., Kauhanen, J., Kemppinen, O., Paton, M., Polkko, J., Schmidt, W., Siili, T., Fabre, C., Wray, J., Wilhelm, M.B., Poitrasson, F., Patel, K., Gorevan, S., Indyk, S., Paulsen, G., Gupta, S., Bish, D., Schieber, J., Gondet, B., Langevin, Y., Geffroy, C., Baratoux, D., Berger, G., Cros, A., D’Uston, C., Forni, O., Gasnault, O., Lasue, J., Lee, Q.-M., Maurice, S., Meslin, P.-Y., Pallier, E., Parot, Y., Pinet, P., Schroder, S., Toplis, M., Lewin, E., Brunner, W., Heydari, E., Achilles, C., Oehler, D., Sutter, B., Cabane, M., Coscia, D., Israel, G., Szopa, C., Dromart, G., Robert, F., Sautter, V., Le Mouelic, S., Mangold, N., Nachon, M., Buch, A., Stalport, F., Coll, P., Francois, P., Raulin, F., Teinturier, S., Cameron, J., Clegg, S., Cousin, A., DeLapp, D., Dingler, R., Jackson, R.S., Johnstone, S., Lanza, N., Little, C., Nelson, T., Wiens, R.C., Williams, R.B., Jones, A., Kirkland, L., Treiman, A., Baker, B., Cantor, B., Caplinger, M., Davis, S., Duston, B., Edgett, K., Fay, D., Hardgrove, C., Harker, D., Herrera, P., Jensen, E., Kennedy, M.R., Krezoski, G., Krysak, D., Lipkaman, L., Malin, M., McCartney, E., McNair, S., Nixon, B., Posiolova, L., Ravine, M., Salamon, A., Saper, L., Stoiber, K., Supulver, K., Van Beek, J., Van Beek, T., Zimdar, R., French, K.L., Iagnemma, K., Miller, K., Summons, R., Goesmann, F., Goetz, W., Hviid, S., Johnson, M., Lefavor, M., Lyness, E., Breves, E., Dyar, M.D., Fassett, C., Blake, D.F., Bristow, T., DesMarais, D., Edwards, L., Haberle, R., Hoehler, T., Hollingsworth, J., Kahre, M., Keely, L., McKay, C., Wilhelm, M.B., Bleacher, L., Brinckerhoff, 
W., Choi, D., Conrad, P., Dworkin, J.P., Floyd, M., Freissinet, C., Garvin, J., Glavin, D., Harpold, D., Jones, A., Mahaffy, P., Martin, D.K., McAdam, A., Pavlov, A., Raaen, E., Smith, M.D., Stern, J., Tan, F., Trainer, M., Meyer, M., Voytek, M., Anderson, R.C., Aubrey, A., Beegle, L.W., Behar, A., Blaney, D., Calef, F., Christensen, L., Crisp, J.A., DeFlores, L., Ehlmann, B., Feldman, J., Feldman, S., Flesch, G., Hurowitz, J., Jun, I., Keymeulen, D., Maki, J., Mischna, M., Morookian, J.M., Parker, T., Pavri, B., Schoppers, M., Sengstacken, A., Simmonds, J.J., Spanovich, N., de la Torre Juarez, M., Webster, C.R., Yen, A., Archer, P.D., Jones, J.H., Ming, D., Morris, R.V., Niles, P., Rampe, E., Nolan, T., Fisk, M., Radziemski, L., Barraclough, B., Bender, S., Berman, D., Dobrea, E.N., Tokar, R., Vaniman, D., Williams, R.M.E., Yingst, A., Lewis, K., Leshin, L., Cleghorn, T., Huntress, W., Manhes, G., Hudgins, J., Olson, T., Stewart, N., Sarrazin, P., Grant, J., Vicenzi, E., Wilson, S.A., Hamilton, V., Peterson, J., Fedosov, F., Golovin, D., Karpushkina, N., Kozyrev, A., Litvak, M., Malakhov, A., Mitrofanov, I., Mokrousov, M., Nikiforov, S., Prokhorov, V., Sanin, A., Tretyakov, V., Varenikov, A., Vostrukhin, A., Kuzmin, R., Clark, B., Wolff, M., McLennan, S., Botta, O., Drake, D., Bean, K., Lemmon, M., Schwenzer, S.P., Anderson, R.B., Herkenhoff, K., Lee, E.M., Sucharski, R., de Pablo Hernandez, M.A., Avalos, J.J.B., Ramos, M., Malespin, C., Plante, I., Muller, J.-P., NavarroGonzalez, R., Ewing, R., Boynton, W., Downs, R., Fitzgibbon, M., Harshman, K., Morrison, S., Dietrich, W., Kortmann, O., Palucis, M., Sumner, D.Y., Williams, A., Lugmair, G., Wilson, M.A., Rubin, D., Jakosky, B., Balic-Zunic, T., Frydenvang, J., Jensen, J.K., Kinch, K., Koefoed, A., Madsen, M.B., Stipp, S.L.S., Boyd, N., Campbell, J.L., Gellert, R., Perrett, G., Pradler, I., VanBommel, S., Jacob, S., Owen, T., Rowland, S., Atlaskin, E., Savijarvi, H., Garcia, C.M., Mueller-Mellin, R., Bridges, J.C., McConnochie, T., Benna, M., Franz, H., Bower, H., Brunner, A., Blau, H., Boucher, T., Carmosino, M., Atreya, S., Elliott, H., Halleaux, D., Renno, N., Wong, M., Pepin, R., Elliott, B., Spray, J., Thompson, L., Gordon, S., Newsom, H., Ollila, A., Williams, J., Vasconcelos, P., Bentz, J., Nealson, K., Popa, R., Kah, L.C., Moersch, J., Tate, C., Day, M., Kocurek, G., Hallet, B., Sletten, R., Francis, R., McCullough, E., Cloutis, E., ten Kate, I.L., Kuzmin, R., Arvidson, R., Fraeman, A., Scholes, D., Slavney, S., Stein, T., Ward, J., Berger, J., and Moores, J.E. (2014) Mars' Surface radiation environment measured with the Mars Science Laboratory's curiosity rover. Science 343: 1244797-1244797.

Hecht, M.H., Kounaves, S.P., Quinn, R.C., West, S.J., Young, S.M.M., Ming, D.W., Catling, D.C., Clark, B.C., Boynton, W.V., Hoffmann, J., DeFlores, L., Gospodinova, K., Kapit, J., and Smith, P.H. (2009) Detection of perchlorate and the soluble chemistry of martian soil at the phoenix lander site. Science 325:64-67.

Hedges, J.I. and Keil, R.G. (1995) Sedimentary organic matter preservation: an assessment and speculative synthesis. Mar Chem 49:81-115.

Hoering, T.C. (1984) Thermal reactions of kerogen with added water, heavy water and pure organic substances. Org Geochem 5:267-278.

Hoffman, N. (2001) Modern geothermal gradients on Mars and implications for subsurface liquids. Conf Geophys Detect Subsurf Water Mars 53:1689-1699.

Huizinga, B.J., Tannenbaum, E., and Kaplan, I.R. (1987) The role of minerals in the thermal alteration of organic matterIII. Generation of bitumen in laboratory experiments. Org Geochem 11:591-604.
Hunt, J.M., Lewan, M.D., and Hennet, R.J.C. (1991) Modeling oil generation with time-temperature index graphs based on the Arrhenius equation. Am Assoc Pet Geol Bull 75:795-807.

Jaeschke, A., Lewan, M.D., Hopmans, E.C., Schouten, S., and Sinninghe Damsté, J.S. (2008) Thermal stability of ladderane lipids as determined by hydrous pyrolysis. Org Geochem 39: 1735-1741.

Johns, W.D. (1979) Clay mineral catalysis and petroleum generation. Annu Rev Earth Planet Sci 7:183-198.

Jurg, J.W. and Eisma, E. (1964) Petroleum hydrocarbons: generation from fatty acid. Science 144:1451-1452.

Kawamura, K., Tannenbaum, E., Huizinga, B.J., and Kaplan, I.R. (1986) Volatile organic acids generated from kerogen during laboratory heating. Geochem J 20:51-59.

Keil, R.G., Montlucon, D.B., Prahl, F.G., and Hedges, J.I. (1994) Sorptive preservation of labile organic matter in marine sediments. Lett Nat 370:549-552.

Kemp, S.J., Wagner, D., and Ingham, M.N. (2012) The mineralogy, surface area and geochemistry of samples from the Wealden Group of southern England. BGS Internal Report IR/10/079. British Geological Survey, Nottingham, UK.

Klingelhöfer, G., Morris, R.V., Bernhardt, B., Schröder, C., Rodionov, D.S., De Souza, P.A., Yen, A.S., Gellert, R., Evlanov, E.N., Zubkov, B., Foh, J., Bonnes, U., Kankeleit, E., Gutlich, P., Ming, D.W., Renz, F., Wdowiak, T., Squyres, S.W., and Arvidson, R.E. (2004) Jarosite and hematite at Meridiani Planum from opportunity's Mossbauer spectrometer. Science 306:1740-1745.

Knoll, A.H., Carr, M., Clark, B., Des Marais, D.J., Farmer, J.D., Fischer, W.W., Grotzinger, J.P., McLennan, S.M., Malin, M., Schröder, C., Squyres, S., Tosca, N.J., and Wdowiak, T. (2005) An astrobiological perspective on Meridiani Planum. Earth Planet Sci Lett 240:179-189.

Kohnen, M.E.L., Damsté, J.S.S., ten Haven, H.L., and de Leeuw, J.W. (1989) Early incorporation of polysulphides in sedimentary organic matter. Nature 341:640-641.

Kohnen, M.E.L., Sinninghe Damsté, J.S., Kock-van Dalen, A.C., Haven, H.L.T., Rullkötter, J., and De Leeuw, J.W. (1990a) Origin and diagenetic transformations of C25 and C30 highly branched isoprenoid sulphur compounds: further evidence for the formation of organically bound sulphur during early diagenesis. Geochim Cosmochim Acta 54:30533063.

Kohnen, M.E.L., Sinninghe Damsté, J.S., Rijpstra, W.I.C., and de Leeuw, J.W. (1990b) Alkylthiophenes as Sensitive Indicators of Palaeoenvironmental Changes: a study of a Cretaceous oil shale from Jordan, Geochemistry of Sulfur in Fossil Fuels. American Chemical Society, Washington, DC. DOI: 10.1021/bk-1990-0429.ch025

Konn, C., Charlou, J.L., Holm, N.G., and Mousis, O. (2015) The production of methane, hydrogen, and organic compounds in ultramafic-hosted hydrothermal vents of the midatlantic ridge. Astrobiology 15:381-399.

Koopmans, M.P., Sinninghe Damsté, J.S., Lewan, M.D., and De Leeuw, J.W. (1995) Thermal stability of thiophene biomarkers as studied by hydrous pyrolysis. Org Geochem 23: 583-596.

Koopmans, M.P., De Leeuw, J.W., Lewan, M.D., and Sinninghe Damste, J.S. (1996) Impact of dia- and catagenesis on sulphur and oxygen sequestration of biomarkers as revealed by artificial maturation of an immature sedimentary rock. Org Geochem 25:391-426.

Koopmans, M.P., Carson, F.C., Sinninghe Damsté, J.S., and Lewan, M.D. (1998) Biomarker generation from Type II-S 
kerogens in claystone and limestone during hydrous and anhydrous pyrolysis. Org Geochem 29:1395-1402.

Kotler, J.M., Hinman, N.W., Yan, B., Stoner, D.L., and Scott, J.R. (2008) Glycine identification in natural jarosites using laser desorption Fourier transform mass spectrometry: implications for the search for life on Mars. Astrobiology 8:253-266.

Kowalewski, I., Schaeffer, P., Adam, P., Dessort, D., Fafet, A., and Carpentier, B. (2010) Formation of H2S and sulfur-rich bitumen from a reservoired heavy oil in the presence of elemental sulfur. Org Geochem 41:951-958.

Krein, E.B. and Aizenshtat, Z. (1994) The formation of isoprenoid sulfur compounds during diagenesis: simulated sulfur incorporation and thermal transformation. Org Geochem 21: 1015-1025.

Lewan, M.D. (1983) Effects of thermal maturation on stable organic carbon isotopes as determined by hydrous pyrolysis of Woodford Shale. Geochim Cosmochim Acta 47:1471-1479.

Lewan, M.D. (1985) Evaluation of petroleum generation by hydrous pyrolysis experimentation. Philos Trans $R$ Soc London Ser A Math Phys Sci 315:123-134.

Lewan, M.D., Winters, J.C., and McDonald, J.H. (1979) Generation of oil-like pyrolyzates from organic-rich shales. Science 185:897-900.

Lewan, M.D., Bjorøy, M., and Dolcater, D.L. (1986) Effects of thermal maturation on steroid hydrocarbons as determined by hydrous pyrolysis of Phosphoria Retort Shale. Geochim Cosmochim Acta 50:1977-1987.

Lewis, J.M.T., Watson, J.S., Najorka, J., Luong, D., and Sephton, M.A. (2015) Sulfate minerals: a problem for the detection of organic compounds on Mars? Astrobiology 15:247-258.

Lewis, J.M.T., Najorka, J., Watson, J.S., and Sephton, M.A. (2018) The search for hesperian organic matter on mars: pyrolysis studies of sediments rich in sulfur and iron. Astrobiology 18:454-464.

Machel, H.G. (2001) Bacterial and thermochemical sulfate reduction in diagenetic settings-old and new insights. Sediment Geol 140:143-175.

McCollom, T.M. and Seewald, J.S. (2006) Carbon isotope composition of organic compounds produced by abiotic synthesis under hydrothermal conditions. Earth Planet Sci Lett 243:74-84.

McCollom, T.M. and Seewald, J.S. (2007) Abiotic synthesis of organic compounds in deep-sea hydrothermal environments. Chem Rev 107:382-401.

McKay, C.P. and Davis, W.L. (1991) Duration of liquid water habitats on early Mars. Icarus 90:214-221.

McLennan, S.M., Anderson, R.B., Bell, J.F., Bridges, J.C., Calef, F., Campbell, J.L., Clark, B.C., Clegg, S., Conrad, P., Cousin, A., Des Marais, D.J., Dromart, G., Dyar, M.D., Edgar, L.A., Ehlmann, B.L., Fabre, C., Forni, O., Gasnault, O., Gellert, R., Gordon, S., Grant, J.A., Grotzinger, J.P., Gupta, S., Herkenhoff, K.E., Hurowitz, J.A., King, P.L., Le Mouelic, S., Leshin, L.A., Leveille, R., Lewis, K.W., Mangold, N., Maurice, S., Ming, D.W., Morris, R.V., Nachon, M., Newsom, H.E., Ollila, A.M., Perrett, G.M., Rice, M.S., Schmidt, M.E., Schwenzer, S.P., Stack, K., Stolper, E.M., Sumner, D.Y., Treiman, A.H., VanBommel, S., Vaniman, D.T., Vasavada, A., Wiens, R.C., Yingst, R.A., Kemppinen, O., Bridges, N., Johnson, J.R., Minitti, M., Cremers, D., Farmer, J., Godber, A., Wadhwa, M., Wellington, D., McEwan, I., Newman, C., Richardson, M., Charpentier, A., Peret, L., Blank, J., Weigle, G., Li, S., Milliken, R., Robertson, K., Sun, V., Baker, M., Edwards, C., Farley, K., Griffes, J., Miller, H., Newcombe, M., Pilorget, C., Siebach, K., Brunet, C., Hipkin, V., Marchand, G., Sanchez, P.S., Favot, L., Cody, G.,
Steele, A., Fluckiger, L., Lees, D., Nefian, A., Martin, M., Gailhanou, M., Westall, F., Israel, G., Agard, C., Baroukh, J., Donny, C., Gaboriaud, A., Guillemot, P., Lafaille, V., Lorigny, E., Paillet, A., Perez, R., Saccoccio, M., Yana, C., ArmiensAparicio, C., Rodriguez, J.C., Blazquez, I.C., Gomez, F.G., Gomez-Elvira, J., Hettrich, S., Malvitte, A.L., Jimenez, M.M., Martinez-Frias, J., Martin-Soler, J., Martin-Torres, F.J., Jurado, A.M., Mora-Sotomayor, L., Caro, G.M., Lopez, S.N., PeinadoGonzalez, V., Pla-Garcia, J., Manfredi, J.A.R., RomeralPlanello, J.J., Fuentes, S.A.S., Martinez, E.S., Redondo, J.T., Urqui-O'Callaghan, R., Mier, M.-P.Z., Chipera, S., Lacour, J.L., Mauchien, P., Sirven, J.-B., Manning, H., Fairen, A., Hayes, A., Joseph, J., Squyres, S., Sullivan, R., Thomas, P., Dupont, A., Lundberg, A., Melikechi, N., Mezzacappa, A., DeMarines, J., Grinspoon, D., Reitz, G., Prats, B., Atlaskin, E., Genzer, M., Harri, A.-M., Haukka, H., Kahanpaa, H., Kauhanen, J., Kemppinen, O., Paton, M., Polkko, J., Schmidt, W., Siili, T., Wray, J., Wilhelm, M.B., Poitrasson, F., Patel, K., Gorevan, S., Indyk, S., Paulsen, G., Bish, D., Schieber, J., Gondet, B., Langevin, Y., Geffroy, C., Baratoux, D., Berger, G., Cros, A., D’Uston, C., Lasue, J., Lee, Q.-M., Meslin, P.-Y., Pallier, E., Parot, Y., Pinet, P., Schroder, S., Toplis, M., Lewin, E., Brunner, W., Heydari, E., Achilles, C., Oehler, D., Sutter, B., Cabane, M., Coscia, D., Israel, G., Szopa, C., Robert, F., Sautter, V., Buch, A., Stalport, F., Coll, P., Francois, P., Raulin, F., Teinturier, S., Cameron, J., DeLapp, D., Dingler, R., Jackson, R.S., Johnstone, S., Lanza, N., Little, C., Nelson, T., Williams, R.B., Jones, A., Kirkland, L., Baker, B., Cantor, B., Caplinger, M., Davis, S., Duston, B., Edgett, K., Fay, D., Hardgrove, C., Harker, D., Herrera, P., Jensen, E., Kennedy, M.R., Krezoski, G., Krysak, D., Lipkaman, L., Malin, M., McCartney, E., McNair, S., Nixon, B., Posiolova, L., Ravine, M., Salamon, A., Saper, L., Stoiber, K., Supulver, K., Van Beek, J., Van Beek, T., Zimdar, R., French, K.L., Iagnemma, K., Miller, K., Summons, R., Goesmann, F., Goetz, W., Hviid, S., Johnson, M., Lefavor, M., Lyness, E., Breves, E., Fassett, C., Blake, D.F., Bristow, T., Edwards, L., Haberle, R., Hoehler, T., Hollingsworth, J., Kahre, M., Keely, L., McKay, C., Wilhelm, M.B., Bleacher, L., Brinckerhoff, W., Choi, D., Dworkin, J.P., Eigenbrode, J., Floyd, M., Freissinet, C., Garvin, J., Glavin, D., Harpold, D., Jones, A., Mahaffy, P., Martin, D.K., McAdam, A., Pavlov, A., Raaen, E., Smith, M.D., Stern, J., Tan, F., Trainer, M., Meyer, M., Posner, A., Voytek, M., Anderson, R.C., Aubrey, A., Beegle, L.W., Behar, A., Blaney, D., Brinza, D., Christensen, L., Crisp, J.A., DeFlores, L., Ehlmann, B., Feldman, J., Feldman, S., Flesch, G., Jun, I., Keymeulen, D., Maki, J., Mischna, M., Morookian, J.M., Parker, T., Pavri, B., Schoppers, M., Sengstacken, A., Simmonds, J.J., Spanovich, N., de la Torre Juarez, M., Webster, C.R., Yen, A., Archer, P.D., Cucinotta, F., Jones, J.H., Niles, P., Rampe, E., Nolan, T., Fisk, M., Radziemski, L., Barraclough, B., Bender, S., Berman, D., Dobrea, E.N., Tokar, R., Williams, R.M.E., Cleghorn, T., Huntress, W., Manhes, G., Hudgins, J., Olson, T., Stewart, N., Sarrazin, P., Vicenzi, E., Wilson, S.A., Bullock, M., Ehresmann, B., Hamilton, V., Hassler, D., Peterson, J., Rafkin, S., Zeitlin, C., Fedosov, F., Golovin, D., Karpushkina, N., Kozyrev, A., Litvak, M., Malakhov, A., Mitrofanov, I., Mokrousov, M., Nikiforov, S., Prokhorov, V., Sanin, A., Tretyakov, V., Varenikov, A., Vostrukhin, A., Kuzmin, R., Wolff, M., Botta, O., Drake, D., Bean, K., Lemmon, M., Lee, E.M., Sucharski, R., de Pablo Hernandez, M.A., Avalos, J.J.B., Ramos, M., Kim, M.-H., Malespin, C., Plante, I., Muller, J.-P., NavarroGonzalez, R., Ewing, R., Boynton, W., Downs, R., Fitzgibbon, M., Harshman, K., Morrison, S., Dietrich, W., Kortmann, O., Palucis, M., Williams, A., Lugmair, G., Wilson, M.A., Rubin, 
D., Jakosky, B., Balic-Zunic, T., Frydenvang, J., Jensen, J.K., Kinch, K., Koefoed, A., Madsen, M.B., Stipp, S.L.S., Boyd, N., Pradler, I., Jacob, S., Owen, T., Rowland, S., Atlaskin, E., Savijarvi, H., Boehm, E., Bottcher, S., Burmeister, S., Guo, J., Kohler, J., Garcia, C.M., Mueller-Mellin, R., WimmerSchweingruber, R., McConnochie, T., Benna, M., Franz, H., Bower, H., Brunner, A., Blau, H., Boucher, T., Carmosino, M., Atreya, S., Elliott, H., Halleaux, D., Renno, N., Wong, M., Pepin, R., Elliott, B., Spray, J., Thompson, L., Williams, J., Vasconcelos, P., Bentz, J., Nealson, K., Popa, R., Kah, L.C., Moersch, J., Tate, C., Day, M., Kocurek, G., Hallet, B., Sletten, R., Francis, R., McCullough, E., Cloutis, E., ten Kate, I.L., Kuzmin, R., Arvidson, R., Fraeman, A., Scholes, D., Slavney, S., Stein, T., Ward, J., Berger, J., and Moores, J.E. (2014) Elemental geochemistry of sedimentary rocks at Yellowknife Bay, Gale Crater, Mars. Science 343:1244734-1244734.

Milliken, R.E. and Bish, D.L. (2010) Sources and sinks of clay minerals on Mars. Philos Mag 90:2293-2308.

Mißbach, H., Schmidt, B.C., Duda, J.P., Lünsdorf, N.K., Goetz, W., and Thiel, V. (2018) Assessing the diversity of lipids formed via Fischer-Tropsch-type reactions. Org Geochem 119:110-121.

Montgomery, W., Bromiley, G.D., and Sephton, M.A. (2016) The nature of organic records in impact excavated rocks on Mars. Sci Rep 6:30947.

Morris, R.V., Bristow, T.F., Rampe, E.B., Yen, A.S., Vaniman, D.T., Tu, V., Thorpe, M.T., Peretyazhko, T.S., Morrison, S.M., Ming, D.W., Hazen, R.M., Downs, R.T., Downs, G.W., Des Marais, D.J., Craig, P.I., Chipera, S.J., Castle, N., Blake, D.F., and Achilles, C.N. (2019) Mineralogy and formation process for the Vera Rubin Ridge in Gale Crater based on XRD analyses by the CheMin instrument on the MSL rover Curiosity. In 50th Lunar and Planetary Science Conference. p 2132 [Abstract], Houston, TX, USA.

Nissenbaum, A. and Kaplan, I.R. (1972) Chemical and isotopic evidence for the in situ origin of marine humic substances. Limnol Oceanogr 17:570-582.

Parenteau, M.N., Jahnke, L.L., Farmer, J.D., and Cady, S.L. (2014) Production and early preservation of lipid biomarkers in iron hot springs. Astrobiology 14:502-521.

Peters, K.E., Moldowan, J.M., and Sundararaman, P. (1990) Effects of hydrous pyrolysis on biomarker thermal maturity parameters: monterey Phosphatic and Siliceous members. Org Geochem 15:249-265.

Poulet, F., Bibring, J.-P., Mustard, J.F., Gendrin, A., Mangold, N., Langevin, Y., Arvidson, R.E., Gondet, B., Gomez, C., Berthé, M., Erard, S., Forni, O., Manaud, N., Poulleau, G., Soufflot, A., Combes, M., Drossart, P., Encrenaz, T., Fouchet, T., Melchiorri, R., Bellucci, G., Altieri, F., Formisano, V., Fonti, S., Capaccioni, F., Cerroni, P., Coradini, A., Korablev, O., Kottsov, V., Ignatiev, N., Titov, D., Zasova, L., Pinet, P., Schmitt, B., Sotin, C., Hauber, E., Hoffmann, H., Jaumann, R., Keller, U., Arvidson, R., Mustard, J., and Forget, F. (2005) Phyllosilicates on Mars and implications for early martian climate. Nature 438:623-627.

Rampe, E.B., Ming, D.W., Blake, D.F., Bristow, T.F., Chipera, S.J., Grotzinger, J.P., Morris, R.V., Morrison, S.M., Vaniman, D.T., Yen, A.S., Achilles, C.N., Craig, P.I., Des Marais, D.J., Downs, R.T., Farmer, J.D., Fendrich, K.V., Gellert, R., Hazen, R.M., Kah, L.C., Morookian, J.M., Peretyazhko, T.S., Sarrazin, P., Treiman, A.H., Berger, J.A., Eigenbrode, J., Fairén, A.G., Forni, O., Gupta, S., Hurowitz, J.A., Lanza, N.L., Schmidt, M.E., Siebach, K., Sutter, B., and Thompson, L.M. (2017) Mineralogy of an ancient lacustrine mudstone succession from the Murray formation, Gale crater, Mars. Earth Planet Sci Lett 471:172-185.
Richardson, M.I. and Mischna, M.A. (2005) Long-term evolution of transient liquid water on Mars. J Geophys Res Planets 110, doi:10.1029/2004JE002367.

Royle, S.H., Tan, J., Kounaves, S.P., and Sephton, M.A. (2018) Survivability of 1-chloronapthalene during simulated early diagenesis: implications for chlorinated hydrocarbon detection on Mars. J Geophys Res Planets 123:2790-2802.

Rush, D., Jaeschke, A., Geenevasen, J.A.J., Tegelaar, E., Pureveen, J., Lewan, M.D., Schouten, S., and Sinninghe Damsté, J.S. (2014) Generation of unusual branched long chain alkanes from hydrous pyrolysis of anammox bacterial biomass. Org Geochem 76:136-145.

Salmon, V., Derenne, S., Lallier-Vergès, E., Largeau, C., and Beaudoin, B. (2000) Protection of organic matter by mineral matrix in a Cenomanian black shale. Org Geochem 31:463-474.

Schimmelmann, A., Boudou, J.P., Lewan, M.D., and Wintsch, R.P. (2001) Experimental controls on D/H and13C/12C ratios of kerogen, bitumen and oil during hydrous pyrolysis. Org Geochem 32:1009-1018.

Seewald, J.S. (2003) Organic-inorganic interactions in petroleumproducing sedimentary basins. Nature 426:327-333.

Sephton, M.A. (2012) Pyrolysis and mass spectrometry studies of meteoritic organic matter. Mass Spectrom Rev 31:560-569.

Shimoyama, A. and Johns, W.D. (1971) Catalytic conversion of fatty acids to petroleum-like paraffins and their maturation. Nat Phys Sci 232:140-144.

Shuster, D.L. and Weiss, B.P. (2005) Martian surface paleotemperatures from thermochronology of meterorites. Science 309:594-597.

Sinninghe Damste, J.S., and De Leeuw, J.W. (1990) Analysis, structure and geochemical significance of organically-bound sulphur in the geosphere: state of the art and future research. Org Geochem 16:1077-1101.

Sinninghe Damsté, J.S., Irene, W., Rijpstra, C., de Leeuw, J.W., and Schenck, P.A. (1988) Origin of organic sulphur compounds and sulphur-containing high molecular weight substances in sediments and immature crude oils. Org Geochem 13:593-606.

Sinninghe Damste, J.S., Rijpstra, W.I.C., Kock-van Dalen, A.C., De Leeuw, J.W., and Schenck, P.A. (1989) Quenching of labile functionalised lipids by inorganic sulphur species: evidence for the formation of sedimentary organic sulphur compounds at the early stages of diagenesis. Geochim Cosmochim Acta 53:1343-1355.

Solomon, D.H. (1968) Clay minerals as electron acceptors and/or electron donors in organic reactions. Clays Clay Miner 16:31-39.

Solomon, D.H. and Rosser, M.J. (1965) Reactions catalyzed by minerals. Part I. Polymerization of styrene. J Appl Polym Sci 9:1261-1271.

Squyres, S.W. and Knoll, A.H. (2005) Sedimentary rocks at Meridiani Planum: origin, diagenesis, and implications for life on Mars. Earth Planet Sci Lett 240:1-10.

Squyres, S.W., Grotzinger, J.P., Arvidson, R.E., Bell J.F., III, Calvin, W., Christensen, P.R., Clark, B.C., Crisp, J.A., Farrand, W.H., Herkenkoff, K.E., Johnson, J.R., Klingelhöfer, G., Knoll, A.H., McLennan, S.M., McSween, H.Y., Jr., Morris, R.V., Rice, J.W., Jr., Rieder, R., and Soderblom, L.A. (2004) In situ evidence for an ancient aqueous environment at Meridiani Planum, Mars. Science 306:709-1714.

Stalker, L., Farrimond, P., and Larter, S.R. (1994) Water as an oxygen source for the production of oxygenated compounds (including $\mathrm{CO} 2$ precursors) during kerogen maturation. Org Geochem 22:477-486.

Summons, R.E., Albrecht, P., McDonald, G., and Moldowan, J.M. (2008) Molecular biosignatures. In Strategies of Life Detection, 
edited by O. Botta, J.L. Bada, J. Gomez-Elvira, E. Javaux, F. Selsis, and R. Summons, Springer US, Boston, MA, pp 133-159. Surdam, R.C. and Crossey, L.J. (1985) Organic-inorganic reactions during progressive burial: key to porosity and permeability enhancement and preservation [and discussion]. Philos Trans $R$ Soc A Math Phys Eng Sci 315:135-156.

Tan, J., Lewis, J.M.T., and Sephton, M.A. (2018) The fate of lipid biosignatures in a mars-analogue sulfur stream. Sci Rep 8:7586.

Tannenbaum, E. and Kaplan, I.R. (1985a) Role of minerals in the thermal alteration of organic matter - I: generation of gases and condensates under dry condition. Geochim Cosmochim Acta 49:2589-2604.

Tannenbaum, E. and Kaplan, I.R. (1985b) Low-Mr hydrocarbons generated during hydrous and dry pyrolysis of kerogen. Nature 317:708-709.

Tannenbaum, E., Ruth, E., and Kaplan, I.R. (1986) Steranes and triterpanes generated from kerogen pyrolysis in the absence and presence of minerals. Geochim Cosmochim Acta 50:805-812.

Tosca, N.J., McLennan, S.M., Clark, B.C., Grotzinger, J.P., Hurowitz, J.A., Knoll, A.H., Schröder, C., and Squyres, S.W. (2005) Geochemical modeling of evaporation processes on Mars: insight from the sedimentary record at Meridiani Planum. Earth Planet Sci Lett 240:122-148.

Tosca, N.J., McLennan, S.M., Dyar, M.D., Sklute, E.C., and Michel, F.M. (2008) Fe oxidation processes at Meridiani Planum and implications for secondary $\mathrm{Fe}$ mineralogy on Mars. J Geophys Res E Planets 113:1-20.

Treiman, A.H., Bish, D.L., Vaniman, D.T., Chipera, S.J., Blake, D.F., Ming, D.W., Morris, R. V, Bristow, T.F., Morrison, S.M., Baker, M.B., Rampe, E.B., Downs, R.T., Filiberto, J., Glazner, A.F., Gellert, R., Thompson, L.M., Schimdt, M.E., Le Deit, L., Wiens, R.C., McAdam, A.C., Achilles, C.N., Edgett, K.S., Farmer, J.D., Fendrich, K.V., Grotzinger, J.P., Gupta, S., Morookian, J.M., Newcombe, M.E., Rice, M.S., Spray, J., Stolper, E.M., Sumner, D.Y., Vasavada, A.R., and Yen, A.S. (2016) Mineralogy, provenance, and diagenesis of a potassic basaltic sandstone on Mars: CheMin X-ray diffraction of the Windjana sample (Kimberley area, Gale Crater). J Geophys Res Planets 121:75-106.

Vago, J.L., Westall, F., Coates, A.J., Jaumann, R., Korablev, O., Ciarletti, V., Mitrofanov, I., Josset, J.-L., Sanctis, M.C. De, Bibring, J.-P., Rull, F., Goesmann, F., Steininger, H., Goetz, W., Brinckerhoff, W., Raulin, F., Edwards, H.G.M., Whyte, L.G., Fairén, A.G., Bridges, J., Hauber, E., Ori, G.G., Werner, S., Loizeau, N.D., Kuzmin, R.O., Williams, R.M.E., Flahaut, J., Forget, F., Rodionov, D., Korablev, O., Svedhem, H., Kminek, G., Strenge, J., Mikhailov, V., Alexashkin, S., Calantropio, F., Poulakis, P., and Bayle, O. (2016) Habitability on early Mars and the search for biosignatures with the ExoMars rover. Astrobiology 17:471-510.

Vairavamurthy, A. and Mopper, K. (1987) Geochemical formation of organosulphur compounds (thiols) by addition of H2S to sedimentary organic matter. Nature 329:623-625.

Vaniman, D.T., Bish, D.L., Ming, D.W., Bristow, T.F., Morris, R. V, and Blake, D.F. (2014) Mineralogy of a mudstone at Yellowknife Bay, Gale Crater, Mars. Science 343:1-9.

Vestal, J.R. and White, D.C. (1989) Lipid analysis in microbial ecology. Bioscience 39:535-541.

Wakeham, S.G. (1995) Lipid biomarkers for heterotrophic alteration of suspended particulate organic matter in oxygenated and anoxic water columns of the ocean. Deep Res Part I 42: 1749-1771.
Watson, J.S. and Sephton, M.A. (2015) Heat, aromatic units, and iron-rich phyllosilicates: a mechanism for making macromolecules in the early solar system. Astrobiology 15:787-792.

Westall, F., Foucher, F., Bost, N., Bertrand, M., Loizeau, D., Vago, J.L., Kminek, G., Gaboyer, F., Campbell, K.A., Bréhéret, J.-G., Gautret, P., and Cockell, C.S. (2015) Biosignatures on Mars: what, where, and how? Implications for the search for martian life. Astrobiology 15:998-1029.

Williams, A.J., Sumner, D.Y., Alpers, C.N., Karunatillake, S., and Hofmann, B.A. (2015) Preserved filamentous microbial biosignatures in the Brick Flat Gossan, Iron Mountain, California. Astrobiology 15:637-668.

Zhang, C.L., Li, Y., Wall, J.D., Larsen, L., Sassen, R., Huang, Y., Wang, Y., Peacock, A., White, D.C., Horita, J., and Cole, D.R. (2002) Lipid and carbon isotopic evidence of methaneoxidizing and sulfate-reducing bacteria in association with gas hydrates from the Gulf of Mexico. Geology 30:239-242.

Zolotov, M.Y. and Shock, E.L. (2005) Formation of jarositebearing deposits through aqueous oxidation of pyrite at Meridiani Planum, Mars. Geophys Res Lett 32:1-5.

Address correspondence to: Jonathan Tan

Department of Earth Science and Engineering Impacts and Astromaterials Research Centre Imperial College London London SW7 2AZ United Kingdom

E-mail: jonathan.tan12@imperial.ac.uk

Submitted 4 February 2019 Accepted 11 September 2019

$\begin{aligned} & \quad \text { Abbreviations Used } \\ & \text { BA }=\text { branched fatty acids } \\ & \text { BSTFA }=99-1 \text { N,O-bis(trimethylsilyl) trifluoroacetamide } \\ & \mathrm{CA}=\text { cyclopropyl fatty acids } \\ & \text { DCM }=\text { dichloromethane } \\ & \mathrm{DI}=\text { deionized } \\ & \mathrm{EOP}=\text { even-over-odd predominances } \\ & \mathrm{FA}=\text { fatty acid } \\ & \mathrm{FTT}=\text { Fischer/Tropsch-type } \\ & \mathrm{GC}=\text { gas chromatography } \\ & \mathrm{GC}-\mathrm{MS}=\text { gas chromatography/mass spectrometry } \\ & \mathrm{HA}=\text { hydroxy-fatty acids } \\ & \mathrm{MSL}=\text { Mars Science Laboratory } \\ & \mathrm{N} / \mathrm{A}=\text { not applicable } \\ & \mathrm{PS}=\text { phytosterols } \\ & \mathrm{SA}=\text { saturated fatty acids } \\ & \mathrm{SAM}=\text { Sample Analysis at Mars } \\ & \mathrm{SRB}=\text { sulfur-reducing bacteria } \\ & \mathrm{TMCS}=\text { trimethylchlorosilane } \\ & \mathrm{TOC}=\text { total organic carbon } \\ & \mathrm{UA}=\text { unsaturated fatty acids } \\ & \mathrm{UV}=\text { ultraviolet } \\ & \mathrm{W}: \mathrm{R}=\text { water-to-rock ratio } \\ & \mathrm{XRD}=\text { X-ray diffraction } \\ &\end{aligned}$

